\title{
The Functional Influence of Burst and Tonic Firing Mode on Synaptic Interactions in the Thalamus
}

\author{
Uhnoh Kim and David A. McCormick \\ Section of Neurobiology, Yale University School of Medicine, 333 Cedar Street, New Haven, Connecticut 06510
}

Thalamocortical and perigeniculate (PGN) neurons can generate action potentials either as $\mathrm{Ca}^{2+}$ spike-mediated highfrequency bursts or as tonic trains. Using dual intracellular recordings in vitro in monosynaptically connected pairs of PGN and dorsal lateral geniculate nucleus (LGNd) neurons, we found that the functional effect of synaptic transmission between these cell types was strongly influenced by the membrane potential and hence the firing mode of both the pre- and postsynaptic neurons. Activation of single action potentials or low-frequency spike trains in PGN or thalamocortical neurons resulted in the generation of PSPs that were $0.5-2.0 \mathrm{mV}$ in amplitude. In contrast, the generation of $\mathrm{Ca}^{2+}$ spike-mediated bursts of action potentials in the presynaptic cell increased these PSPs to an average of $4.4 \mathrm{mV}$ for the IPSP and $3.0 \mathrm{mV}$ for

Thalamocortical and thalamic reticular (perigeniculate) neurons exhibit two distinct modes of action potential generation. During periods of slow wave sleep, rhythmic burst firing mediated by the activation of low-threshold $\mathrm{Ca}^{2+}$ spikes is prevalent, whereas during waking, activity in both cell types is dominated by the occurrence of trains of action potentials (Mukhametov et al., 1970a,b; McCarley et al., 1983; Domich et al., 1986; Steriade et al., 1986; Guido and Weyand, 1995; Weyand et al., 1997). During slow wave sleep, the interactions of these two cell types are responsible for the generation of spindle waves, which are characterized by $1-3 \mathrm{sec}$ periods of $6-14 \mathrm{~Hz}$ oscillation (Steriade and Deschênes, 1984; Steriade et al., 1993; Bal et al., 1995a,b). During the generation of spindle waves, thalamocortical neurons in the dorsal lateral geniculate nucleus (LGNd) receive repetitive barrages of IPSPs that are generated via the burst firing of the GABAergic perigeniculate (PGN) neurons. These IPSPs result in the occasional generation of rebound low-threshold $\mathrm{Ca}^{2+}$ spikes and bursts of action potentials, which then re-excite the PGN cells as well as transmit the spindle wave to the cerebral cortex (Bal et al., 1995a,b; Contreras and Steriade, 1995). Interestingly, at least some types of generalized epileptic seizures are also believed to depend on rhythmic burst firing in thalamic and thalamocortical circuits (Avoli et al., 1990; Hosford et al., 1992; Snead, 1995).

The interactions between the GABAergic neurons of the thalamic reticular or perigeniculate nuclei and the thalamocortical

\footnotetext{
Received Feb. 11, 1998; revised Aug. 25, 1998; accepted Aug. 28, 1998.

This research was supported by grants from the National Institutes of Health, the Klingenstein Fund, the McKnight Foundation, and the Human Frontiers Science Program. Additional information about these and related findings may be obtained at http://info.med.yale.edu/neurobio/mccormick/mccormick.html.

Correspondence should be addressed to Dr. David A. McCormick, Section of Neurobiology, Yale University School of Medicine, 333 Cedar Street, New Haven, CT 06510.

Copyright (C) 1998 Society for Neuroscience $\quad 0270-6474 / 98 / 189500-17 \$ 05.00 / 0$
}

the EPSP barrage, because of temporal summation and/or facilitation. If the postsynaptic neuron was at a resting membrane potential (e.g., $-65 \mathrm{mV}$ ), these PSP barrages could result in the activation of a low-threshold $\mathrm{Ca}^{2+}$ spike and burst of action potentials. These results demonstrate that the burst firing mode of action potential generation is a particularly effective means by which perigeniculate and thalamocortical neurons may influence one another. We propose that the activation of burst discharges in these cell types is essential for the generation of some forms of synchronized rhythmic oscillations of sleep and of epileptic seizures.

Key words: inhibition; excitation; perigeniculate; thalamocortical; thalamic reticular; spindle waves

cells during the waking, or tonic discharge, state are less well understood. In the dorsal lateral geniculate nucleus, these interactions have been suggested to contribute to feedforward and feedback, as well as binocular and far-field, inhibition within the LGNd (Lindström, 1982; Sillito and Kemp, 1983; Ahlsen et al., 1985; Eysel et al., 1987; Lindström and Wróbel, 1990).

Intracellular and extracellular recordings from numerous cell types in varying regions of the mammalian brain, including the neocortex, hippocampus, superior colliculus, and brainstem, indicate that neurons that generate either burst, tonic, or both types of activity are relatively common (e.g., Kandel and Spencer, 1961; Evarts, 1964; Llinás, 1988; Steriade et al., 1990; Nuñez et al., 1993; Wang and McCormick, 1993; Munoz and Wurtz, 1995; Gray and McCormick, 1996). The functional consequences of these two modes of action potentials have not been examined in detail in the mammalian brain. In many excitatory synaptic pathways, rapid repetitive activation results in facilitation of the postsynaptic depolarization. This facilitation occurs in part indirectly via decreases in disynaptic inhibition but also directly from increases in the efficacy of excitatory transmission, which often result from an increase in the amount of transmitter released by the presynaptic terminal with each action potential (see Zucker, 1989, 1993; Fisher et al., 1997). In particular, detailed examination of the connections between pyramidal cells and GABAergic interneurons in the hippocampus and cerebral cortex suggests that a burst of action potentials in the pyramidal cell may markedly facilitate synaptic transmission between these excitatory and inhibitory neurons (Miles, 1990; Thomson et al., 1993a; Thomson and Deuchars, 1997; see however Debanne et al., 1995). At the same time, synaptic connections between pyramidal cells may exhibit depression or facilitation with repetitive activation (Miles and Wong, 1986; Thomson et al., 1993b; Markram and Tsodyks, 1996; Thomson, 1997). 
Intracellular studies of neurons maintained in the ferret LGNd and PGN slice provide a unique opportunity to examine the properties of these two modes of action potential generation on synaptic transmission in the mammalian brain, because this preparation functionally maintains the extensive connections between the excitatory thalamocortical and inhibitory PGN neurons (e.g., Bal et al., 1995a,b; Kim et al., 1995, 1997). Here we provide evidence that the mode of operation of synaptic circuits within the thalamus depends critically on the membrane potential and firing mode of both the pre- and postsynaptic cells.

\section{MATERIALS AND METHODS}

Sagittal slices of the ferret LGNd and PGN were formed as described previously and were maintained at $35^{\circ} \mathrm{C}$ in an interface style recording chamber (Bal et al., 1995a). The bathing medium contained (in $\mathrm{mm}$ ): $\mathrm{NaCl}, 124 ; \mathrm{KCl}, 2.5 ; \mathrm{MgSO}_{4}, 1.2 ; \mathrm{NaH}_{2} \mathrm{PO}_{4}, 1.25 ; \mathrm{CaCl}_{2}, 2 ; \mathrm{NaHCO}_{3}$, 26; and dextrose, 10; this medium was aerated with $95 \% \mathrm{O}_{2} / 5 \% \mathrm{CO}_{2}$ to a final $\mathrm{pH}$ of 7.4. Dual intracellular recordings were obtained from monosynaptically coupled pairs of neurons by obtaining first an intracellular recording from a PGN neuron with a Leitz (Wetzlar, Germany) micromanipulator followed by intracellular recordings from thalamocortical neurons in the adjacent A or A1 laminae of the LGNd with a Narishige (Tokyo, Japan) three-dimensional hydraulic micromanipulator. Capacitance coupling between the two electrodes was minimized by wrapping each recording electrode in a parafilm sheet and by placing a grounded metallic sheet between the two electrodes.

Intracellular recording electrodes were formed on a Sutter Instruments P-80 micropipette puller from medium-walled glass (1BF100; WPI) and were beveled on a Sutter Instruments beveler. Micropipettes were filled with $1.2 \mathrm{M}$ potassium acetate and $2 \%$ biocytin for intracellular labeling of recorded neurons and had resistances of between 60 and $100 \mathrm{M} \Omega$. Biocytin-filled neurons were visualized via the standard avidin-biotinhorseradish peroxidase reaction with diaminobenzidine (Horikawa and Armstrong, 1988). Neurons were reconstructed by the use of camera lucida with 60 or $100 \times$ objectives.

Some portions of the data obtained from the 41 pairs of PGN to LGNd cells have been published elsewhere (Kim et al., 1997).

\section{RESULTS}

Dual intracellular recordings were obtained from 45 pairs of monosynaptically connected PGN and thalamocortical (LGNd) neurons in the ferret geniculate slice maintained in vitro (40 pairs, PGN to LGNd; 4 pairs, LGNd to PGN; and 1 pair, both directions). The properties of synaptic transmission between these two types of neuron were examined via the injection of depolarizing and hyperpolarizing current pulses in the presynaptic neuron to activate tonic trains or bursts of action potentials. In addition, the membrane potential of the pre- and postsynaptic neurons was manipulated via the intracellular injection of DC.

The properties of synaptic transmission between PGN and thalamocortical cells are summarized in Figure 1. Single action potentials in PGN neurons evoked monosynaptic IPSPs that were $0.5-1.9 \mathrm{mV}$ in amplitude in thalamocortical cells (Fig. 1B), whereas single action potentials in thalamocortical cells evoked EPSPs that were 0.7-2.0 mV in amplitude in PGN cells (Fig. 1G). The activation of prolonged trains of action potentials in PGN or thalamocortical neurons resulted in trains of IPSPs or EPSPs, respectively, that exhibited temporal summation in the postsynaptic neuron (Fig. $1 C, H$ ). Activation of a low-threshold $\mathrm{Ca}^{2+}$ spike-mediated burst in the presynaptic neuron resulted in a large summated IPSP or EPSP barrage in the postsynaptic cell (Fig. $1 D, I)$. Functionally, the activation of an IPSP by the burst discharge of a single PGN cell could result in the generation of a rebound low-threshold $\mathrm{Ca}^{2+}$ spike in the thalamocortical cell (Fig. $1 E$ ), and the activation of an EPSP barrage by a burst of action potentials in the thalamocortical cell could activate a low-threshold $\mathrm{Ca}^{2+}$ spike and burst of action potentials in the PGN neuron (Fig. $1 J$ ).

\section{Perigeniculate inhibition of thalamocortical neurons: single-spike and tonic activity}

The generation of action potentials at low frequencies $(\sim 1 \mathrm{~Hz})$ in PGN neurons that were monosynaptically connected with a simultaneously recorded LGNd cell resulted in IPSPs with a relatively fixed latency of $\sim 1 \mathrm{msec}$. The mean amplitude of these single IPSPs varied considerably among different pairs of cells, ranging from just above the noise level $(0.1-0.2 \mathrm{mV})$ to $1.01 \pm$ $0.30 \mathrm{mV}$ in the most strongly connected pair in our sample $(n=$ 15 pairs analyzed). Single-spike-evoked IPSPs reached their peak amplitude within $2-5 \mathrm{msec}$ from onset and exhibited a duration at half-amplitude of $10-50 \mathrm{msec}$ (Fig. $2 A, B$ ), which was similar to the membrane time constants $(14-37 \mathrm{msec} ; n=6$ pairs), measured from a 5 to $10 \mathrm{mV}$ change in membrane potential in response to the injection of a hyperpolarizing current pulse.

The relationship between the frequency of action potential activity in the PGN cell and the amplitude of the resulting postsynaptic IPSPs was systematically examined. When a train of two to five action potentials was evoked in the PGN cell in the frequency range of $5-80 \mathrm{~Hz}(n=5$ pairs analyzed), the activation of the first IPSP either had little effect or resulted in the depression of the second IPSP. For example, in three connected pairs (see Fig. $2 D a, D b, E$, pairs 1 and 2), the sizes of the second IPSPs varied independently of that of the first, and the mean sizes of the first and second IPSPs were not significantly different. However, in pair 3 (Fig. 2Dc,E), the second IPSP was consistently depressed in amplitude, as was evident in the significantly smaller mean size of the second IPSPs $(0.75 \pm 0.27 \mathrm{mV})$ compared with that of the first $(0.95 \pm 0.19 \mathrm{mV}$; paired $t$ test, $p=0.003)$. In pair 4 (Fig. $2 D c, D d, E)$, the depression of the second IPSP occurred in association with the activation of a large first IPSP. The mean size of the second IPSP, given that the first IPSP was larger than average, was $0.67 \pm 0.09 \mathrm{mV}$ and was significantly smaller than the average of the first IPSPs in all trials $(0.88 \pm 0.31 \mathrm{mV} ; p=0.03)$. In contrast, the mean size of the second IPSP after a first IPSP that was smaller than average was $0.85 \pm 0.13 \mathrm{mV}$ and, therefore, was not significantly different from the average of the first IPSPs.

The generation of repetitive trains of action potentials at frequencies greater than $\sim 20-50 \mathrm{~Hz}$ resulted in temporal summation of postsynaptic IPSPs (Fig. 3). There were two phases in this summation. During the initial 30-50 msec, the IPSPs summated markedly, depending on the frequency of presynaptic activity (Fig. 3Ba,Bb). However, after this time period, the individual IPSPs decreased in amplitude as did the compound IPSP (Fig. 3A,D).

In part because of temporal summation, the peak amplitude of the compound IPSP increased relatively linearly with increasing rate of presynaptic action potential generation (Fig. $3 B b$ ). However, at higher frequencies of activation $(>100 \mathrm{~Hz})$, the amplitude of the compound IPSP was substantially larger than expected, given the amplitude of the single-spike IPSPs. Under these circumstances, the average amplitude of the single-spike IPSPs during the tonic train of action potentials increased with increasing discharge rate of the PGN cell and was larger than was the mean amplitude of single IPSPs activated at $\sim 1 \mathrm{~Hz}$ (Fig. $3 B c$ ).

Facilitation during the first three IPSPs generated at higher frequencies $(>100 \mathrm{~Hz})$ was examined more closely. Plots of amplitudes of the first versus second or third IPSPs activated 


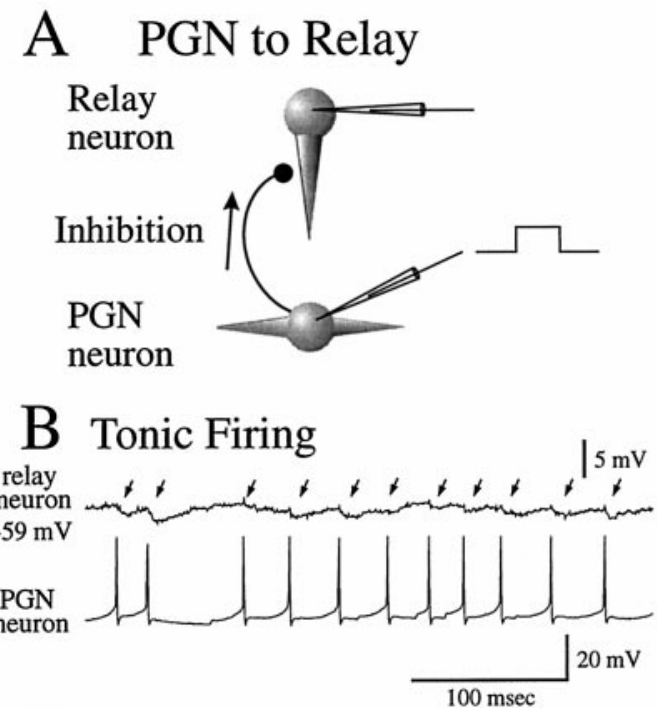

$\mathrm{C}$
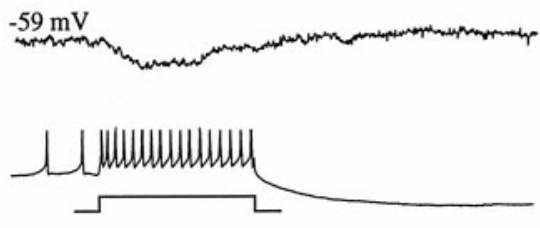

\section{Pre-synaptic Burst}
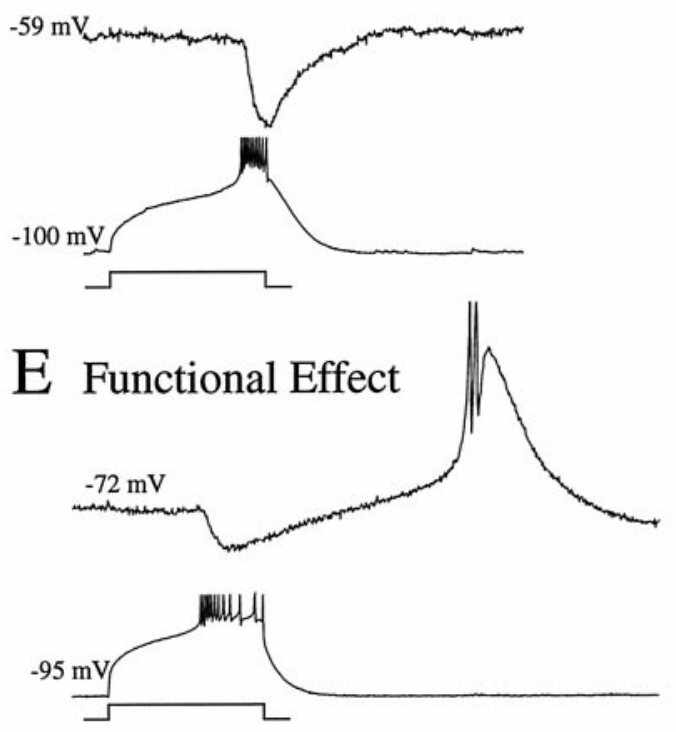

\section{F Relay to PGN}

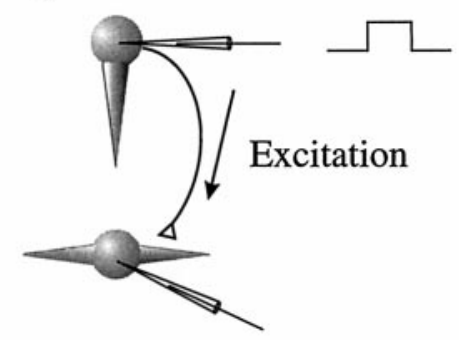

G
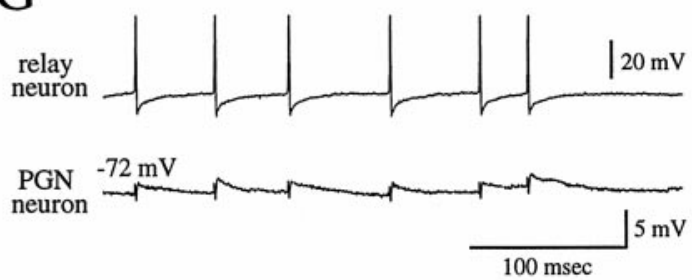

$\mathrm{H}$

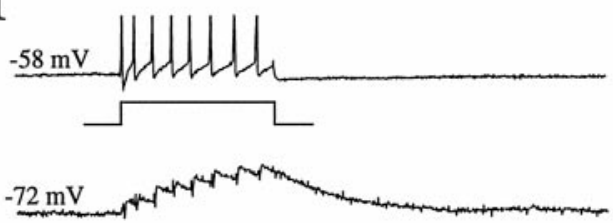

I
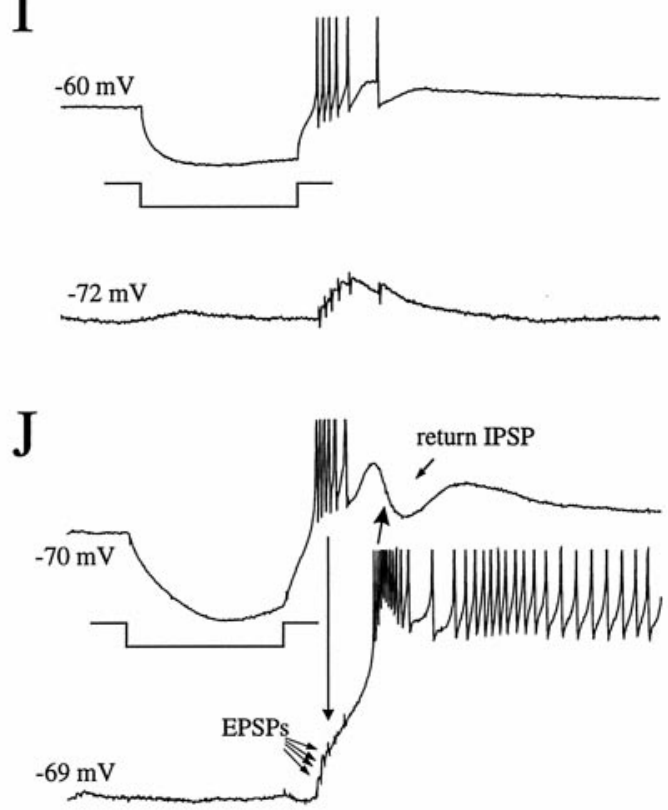

Figure 1. Properties of synaptic connections between PGN and thalamocortical neurons. $A$, Schematic diagram of the recording arrangement for recordings in $B-E$ is shown. The PGN neuron was activated via the intracellular injection of a depolarizing current pulse while recording from a recipient thalamocortical neuron in lamina A of the LGNd. B, Low-frequency $(20-50 \mathrm{~Hz})$ tonic firing in the PGN neuron activates small (0.5-1.9 mV) IPSPs in the thalamocortical cell (arrows). C, Increasing the frequency of discharge of the PGN neuron to an average of $170 \mathrm{~Hz}$ results in temporal summation of the IPSPs. $D$, Activation of a burst discharge in the PGN neuron results in a larger summated IPSP in the postsynaptic thalamocortical cell. $E$, Activation of a presynaptic burst in a PGN neuron could activate a rebound $\mathrm{Ca}^{2+}$ spike and burst in a thalamocortical cell. $F$, Schematic diagram of the recording arrangement for recordings in $G-J$ is shown. The thalamocortical cell was activated with the intracellular injection of current. $G$, Low-frequency $(10-30 \mathrm{~Hz}$ ) firing in the thalamocortical neuron resulted in $0.7-2.0 \mathrm{mV}$ EPSPs in the PGN cell. $H$, Increasing the discharge of the thalamocortical cell to an average of $80 \mathrm{~Hz}$ results in temporal summation of the EPSPs. I, A presynaptic burst of action potentials in the thalamocortical cell results in a summated barrage of EPSPs in the PGN neuron. $J$, Activation of a presynaptic burst in a thalamocortical cell could activate a burst in a PGN neuron, which then could activate a barrage of IPSPs in the thalamocortical cell. The upward-and downward-pointing arrows indicate temporal correlation between burst of action potentials and the activation of postsynaptic potentials. Data are from four different cell pairs $(B-D, E, G-I, J)$. 


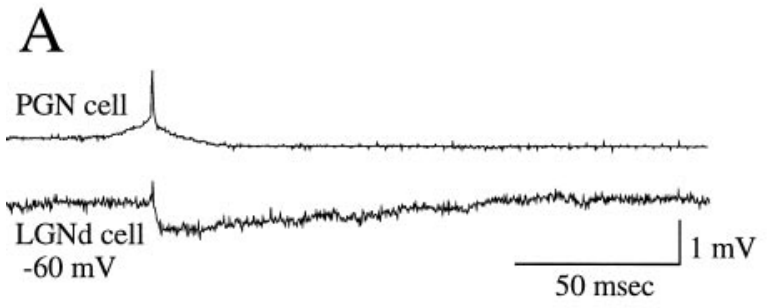

C

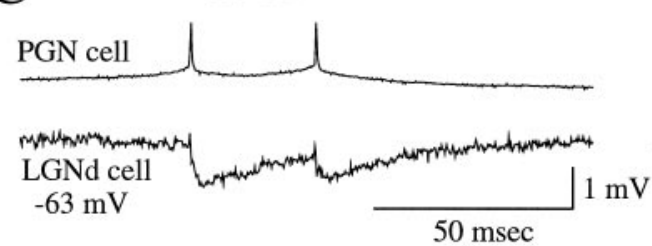

Da mean sizes of

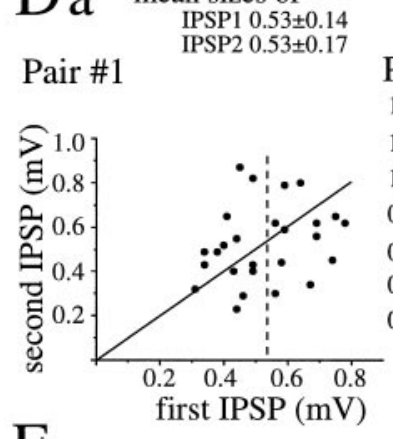

b

$50 \mathrm{msec}$
Pair \#2

IPSP1 $0.80 \pm 0.20$ IPSP2 $0.73 \pm 0.21$

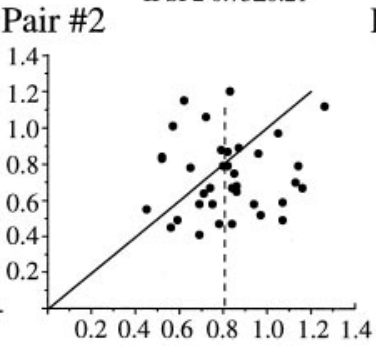

B

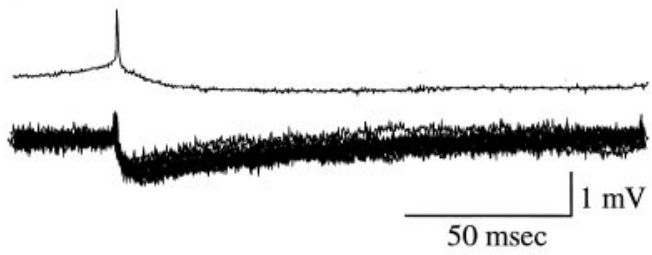

E

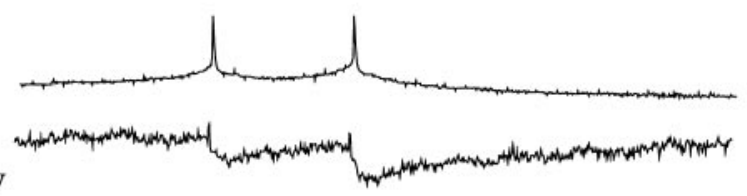

c

IPSP1 $0.95 \pm 0.19$
IPSP2
$0.75 \pm 0.27$

Pair \#3

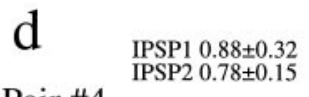

Pair \#4
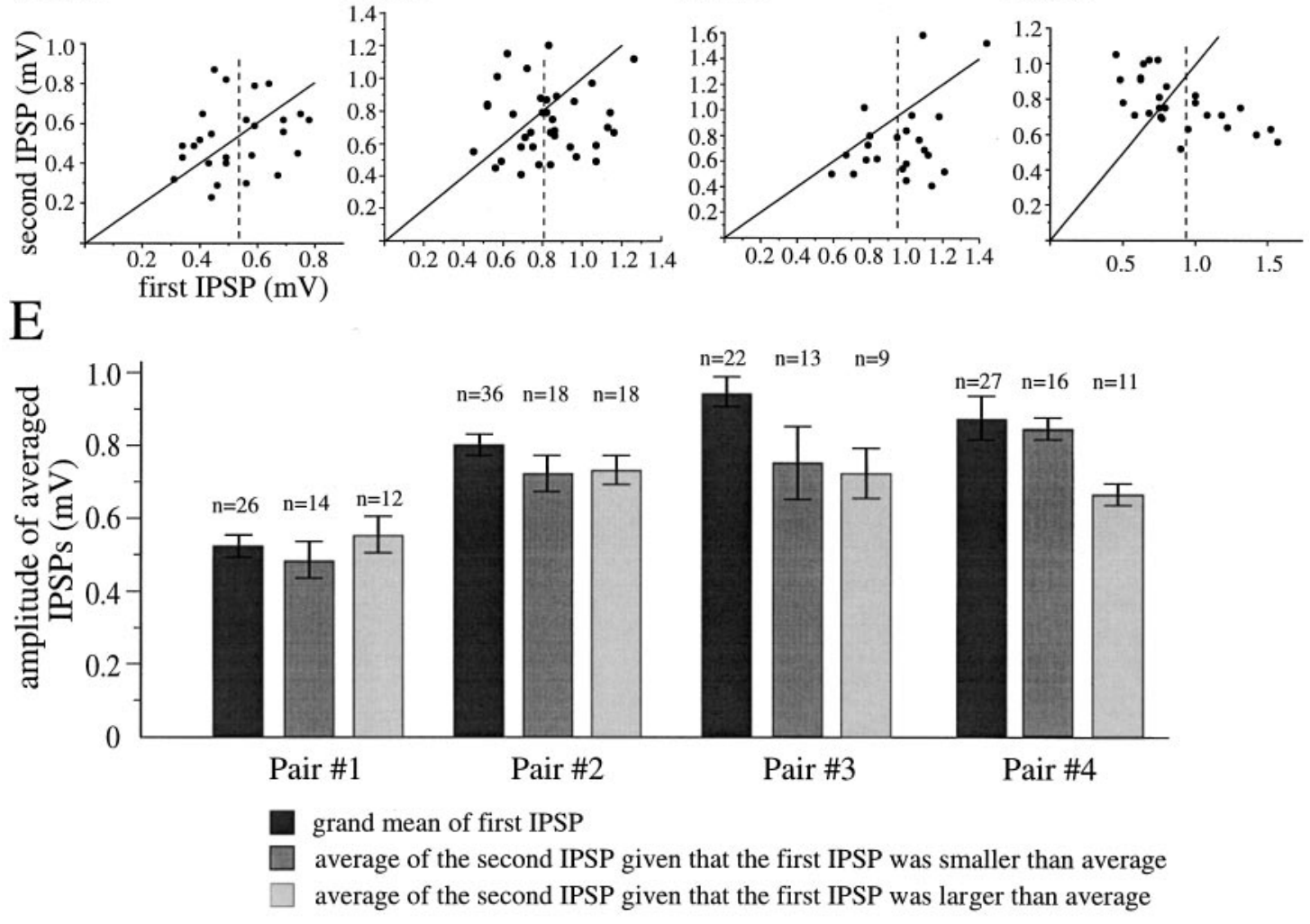

Figure 2. Properties of synaptic transmission from PGN to thalamocortical cells at low frequencies. $A$, Activation of single action potentials at $\sim 1 \mathrm{~Hz}$ in the PGN cell with the intracellular injection of depolarizing current results in single IPSPs in the postsynaptic thalamocortical neuron. $B$, Overlap of 20 single IPSPs is shown. The single IPSPs range from 0.6 to $1.2 \mathrm{mV}$ in amplitude. $C$, Examples of the increase and decrease in the size of the second IPSPs activated at interspike frequencies of $5-80 \mathrm{~Hz}$ are shown. $D a-D c$, Plots of sizes of the first versus the second IPSPs that are activated in the frequency range of $5-80 \mathrm{~Hz}$ in four different pairs are shown. The mean sizes of the first IPSPs in these pairs were $0.53,0.80,0.95$, and $0.88 \mathrm{mV}$, whereas those of the second IPSPs were $0.53,0.73,0.75$, and $0.78 \mathrm{mV}$, respectively. The diagonal lines indicate no change in amplitude between the first and second IPSPs. The vertical dotted lines indicate the mean sizes of the first IPSPs. $E$, In pairs 1 and 2, the sizes of the second IPSPs are not significantly different from those of the first IPSPs, whereas in pair 3, the second IPSPs are consistently depressed in amplitude. In pair 4, the amplitude of the second IPSPs decreased if the first IPSP was larger than average.

during a train of presynaptic action potentials at $150-300 \mathrm{~Hz}$ revealed that the second and third IPSPs were consistently larger than was the first irrespective of the amplitude of the first IPSPs (Fig. 3Ca). The facilitation in single-spike IPSP amplitude was greater for the third IPSP than for the second. The mean size of the second IPSPs was 1.4-1.6 times larger than was that of the first IPSP, whereas the mean amplitude of the third IPSP was 1.8-2.1 times larger ( $n=6$ pairs). The degree of facilitation increased with increasing rate of discharge of the presynaptic PGN cell (Fig. 3Cb). 


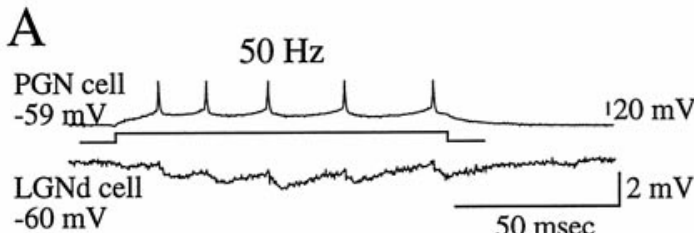

$130 \mathrm{~Hz}$

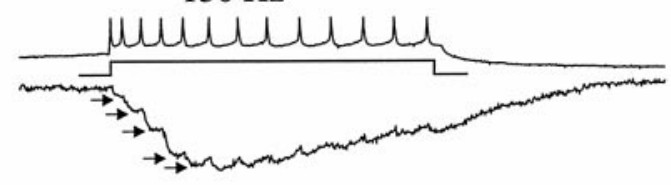

$\mathrm{Ba}$

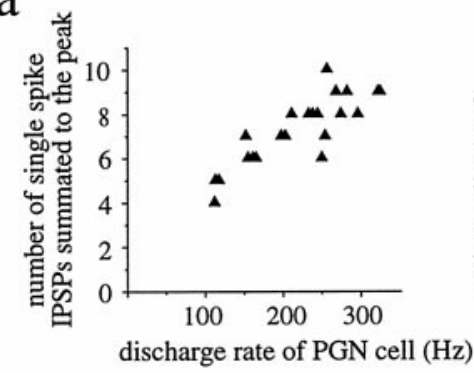

$\mathrm{Ca}$

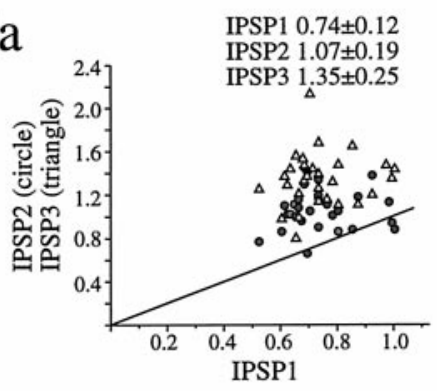

$\mathrm{D}$

$395 \mathrm{~Hz}$
$100 \mathrm{~Hz}$

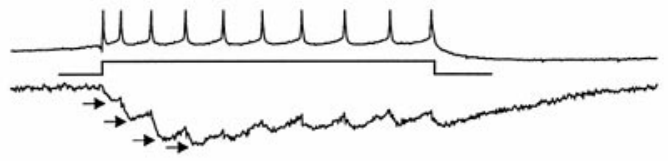

$200 \mathrm{~Hz}$

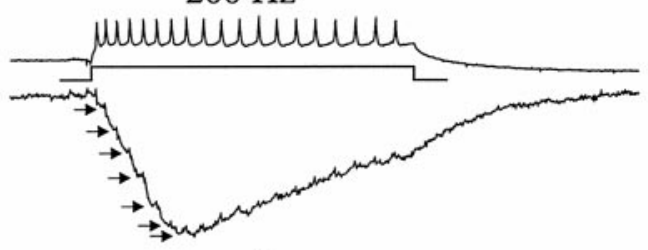

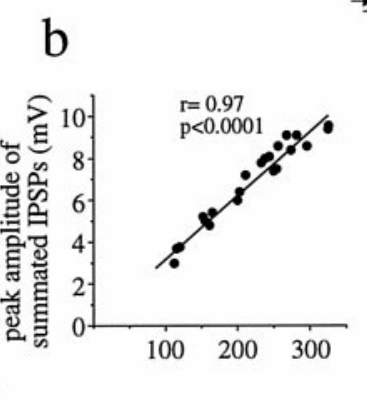
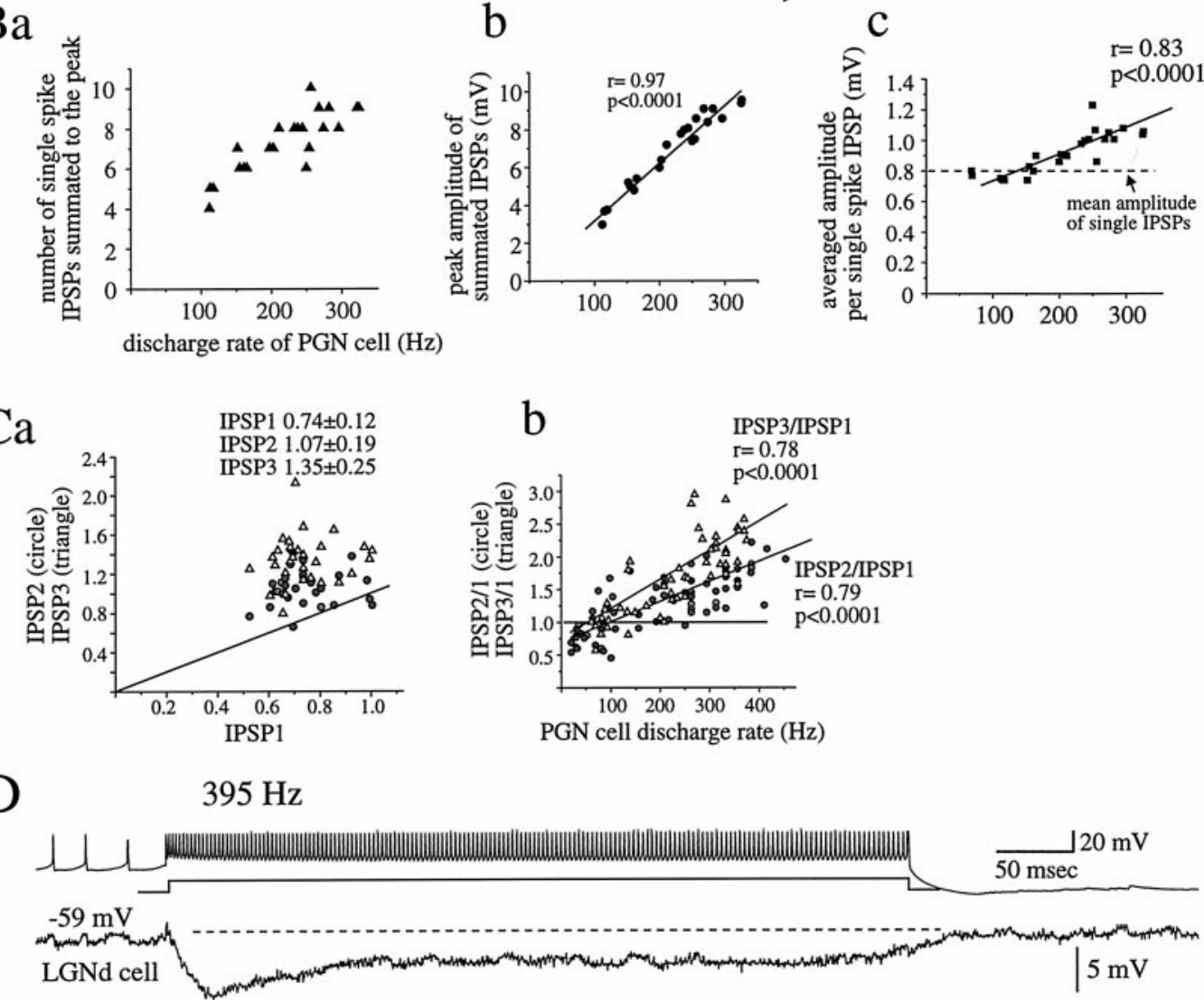

Figure 3. High-frequency discharge results in summation and facilitation in PGN to LGNd synaptic transmission. $A$, When action potentials are generated at $>100 \mathrm{~Hz}$ in frequency, the amplitudes of the first four to six IPSPs (arrows) progressively increase, followed by individual IPSPs of diminished amplitude. The number above each trace is the average frequency of action potential discharge. $B a$, The number of single-spike IPSPs that contribute to the peak amplitude increases with increasing rate of presynaptic action potential generation. $B b$, The peak amplitude of summated IPSPs increases with increasing rate of action potential generation. $B c$, The averaged amplitude per single-spike IPSP (peak amplitude of summated IPSPs/number of action potentials) also grows with increasing rate of action potential generation and is larger than the mean of single IPSPs activated at an interspike frequency of $\sim 1 \mathrm{~Hz}$ (horizontal dashed line), indicating facilitation in synaptic transmission during the high-frequency action potential generation. $C$, Amplitude of facilitation in the initial IPSPs is frequency dependent. $C a$, Plot of amplitudes of the second and third individual IPSPs versus the first activated by a train of presynaptic action potentials at $150-300 \mathrm{~Hz}$ are shown. The diagonal line indicates no change in the amplitude. $\mathrm{Cb}$, Plots of amplitude ratios of the second and third IPSPs to the first as a function of discharge rate of the presynaptic PGN cell are shown. The ratios increase with increasing rate of the action potential generation. The horizontal line indicates no change in the amplitude between the first and the second or third IPSPs. The diagonal lines represent the best-fit linear regression, exhibiting that the magnitude of facilitation is larger in the third IPSP in comparison with the second. $D$, Despite maintained discharge of the PGN cell at high frequency, the summated IPSPs reach a peak and then decline gradually in amplitude to a steady state level. Data in $A-C$ are from one cell pair and in $D$ are from another.

\section{Perigeniculate inhibition of thalamocortical neurons: burst discharge}

The generation of bursts of action potentials in PGN cells, via the activation of a low-threshold $\mathrm{Ca}^{2+}$ spike, resulted in a 350-550 $\mathrm{Hz}$ barrage of IPSPs in the postsynaptic cell (Fig. $4 A, B$ ), the temporal summation and facilitation of which resulted in compound IPSPs that were up to $11.06 \pm 0.78 \mathrm{mV}$ in amplitude in the most strongly connected pair of cells from our sample. Because the time-to-peak of single IPSPs ranged from 2.5 to $3.2 \mathrm{msec}$ on average among pairs of cells ( $n=15$ pairs), the single-spike 

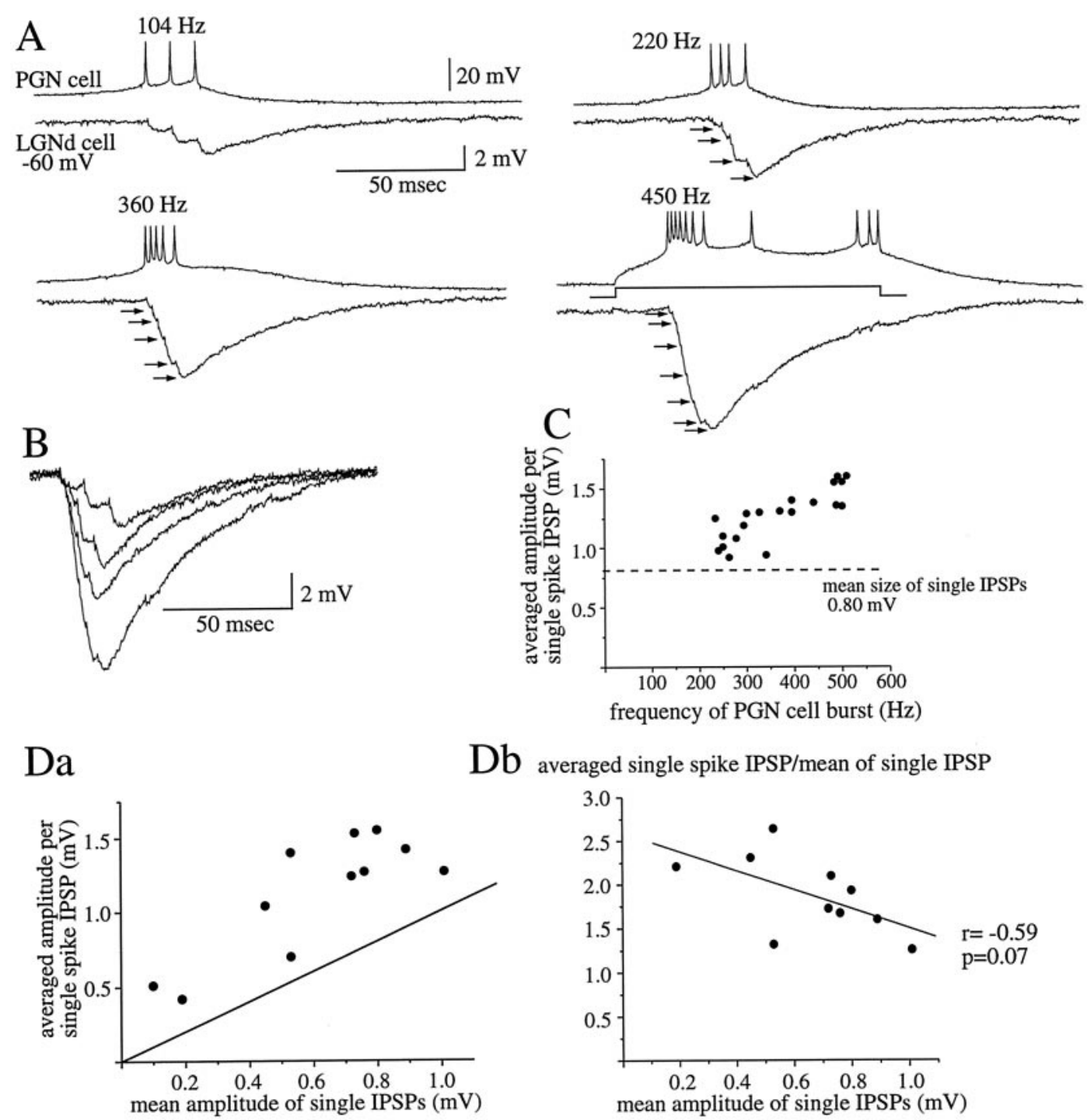

$\mathrm{Db}$ averaged single spike IPSP/mean of single IPSP

$\mathrm{E}$

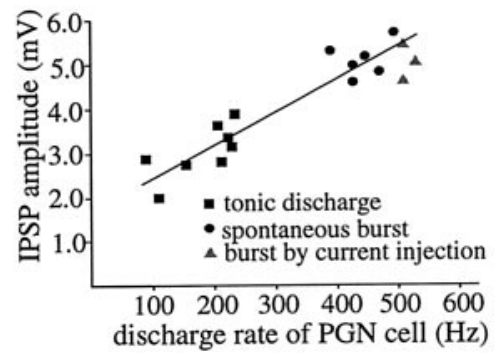

averaged single spike IPSP/mean of single IPSP
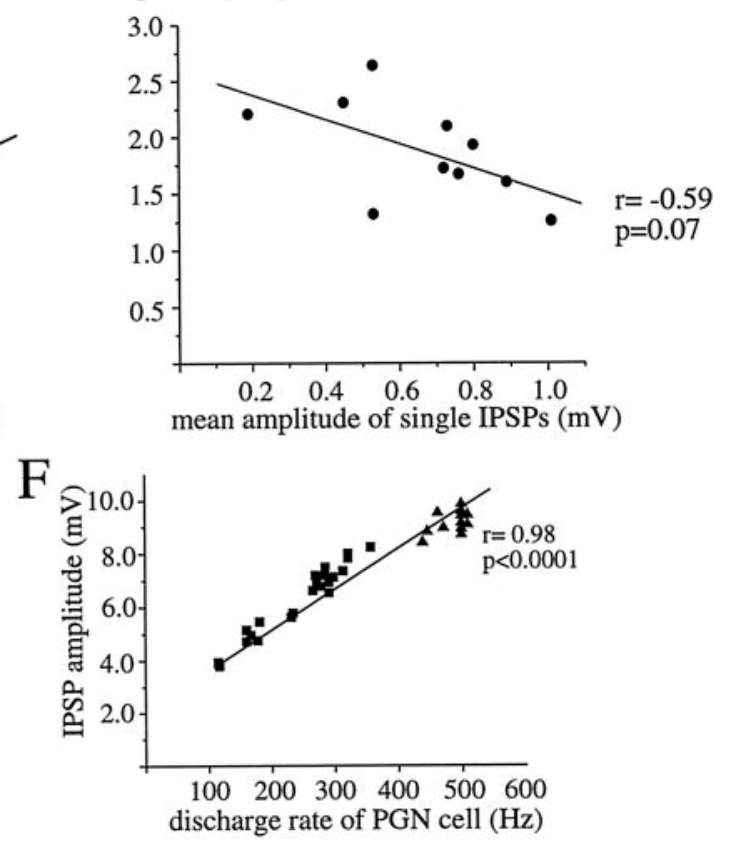

Figure 4. Burst discharges are associated with summation and facilitation of IPSPs from the PGN to LGNd. $A$, A burst discharge of action potentials results in the summated IPSPs that increase in peak amplitude with increasing rate of presynaptic action potential generation. Note that each action potential, even at $450 \mathrm{~Hz}$, results in a postsynaptic IPSP. The frequency of action potentials is an average during the burst. $B$, Overlap of the summated IPSPs in $A$ is shown. $C$, The averaged amplitude per single-spike IPSP grows progressively above the mean size of single IPSPs activated at $1 \mathrm{~Hz}$ (horizontal dashed line) with increasing rate of action potential generation. $D a$, The averaged amplitude per single-spike IPSP is plotted as a function of the mean size of single IPSPs at $1 \mathrm{~Hz}$ in 11 different pairs. In each pair, the mean size of single IPSPs at $1 \mathrm{~Hz}$ was calculated over $30-60$ trials, whereas the averaged amplitude per single-spike IPSP during burst generation was derived from averaging 10-20 bursts of action potentials at 450-550 Hz. In every pair, the averaged amplitude per single-spike IPSP during a burst is larger than is the mean size of single IPSPs activated at low frequencies. These results are indicative of facilitation in synaptic transmission during the burst of high-frequency action potentials. The diagonal line indicates no change in amplitude. Each point represents the average from a single pair. $D b$, The ratio of the average amplitude per single-spike IPSP during a burst to the mean amplitude of low-frequency single IPSPs was plotted as a function of the mean size of single IPSPs. The amplitude ratio shows a tendency to decrease in pairs of larger mean sizes of single IPSPs, although this result does not reach statistical significance. $E, F$, Relationship between the amplitude of the compound IPSP after four $(E)$ or six $(F)$ action potentials and the frequency of action potential generation in the tonic and burst firing mode in two cell pairs are shown. 


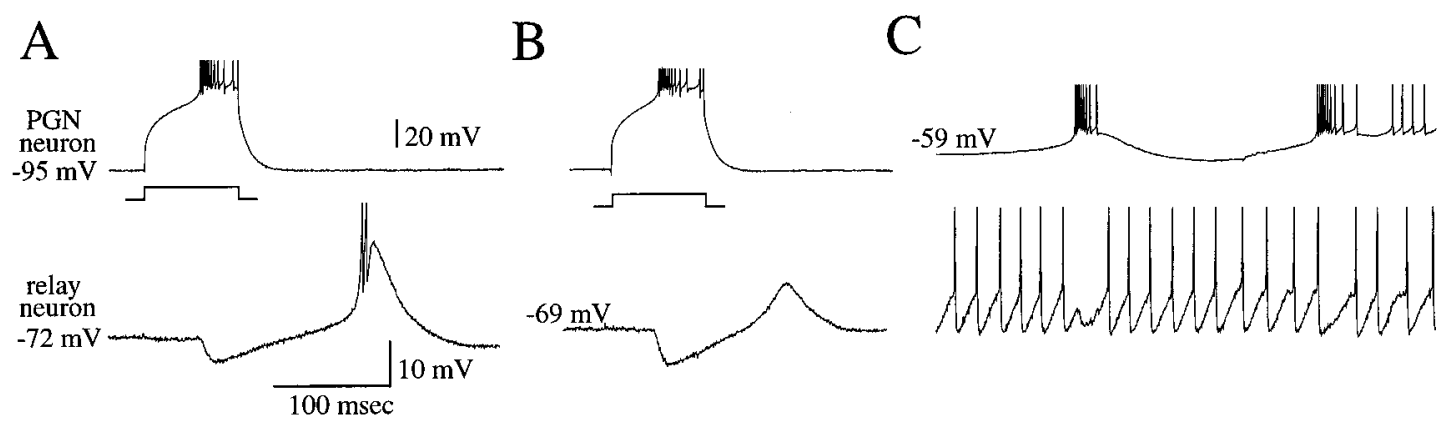

Figure 5. Membrane potential of the thalamocortical cell determines the functional effect of presynaptic bursts in a PGN cell. $A, B$, Depolarization of the thalamocortical cell by only $3 \mathrm{mV}$ results in abolition of rebound burst firing $[-72 \mathrm{mV}(A)$ to $-69 \mathrm{mV}(B)]$. $C$, Further depolarization of the thalamocortical cell to tonic firing mode reveals that presynaptic bursts in the PGN neuron can inhibit the generation of action potentials.

IPSPs activated during the burst discharge of action potentials at $350-550 \mathrm{~Hz}$ presumably overlapped in their temporal development, and therefore it was not possible to measure the true amplitude of individual IPSPs during the burst. For this reason, we calculated the average amplitude per single-spike IPSPs by dividing the peak amplitude of the postsynaptic compound IPSPs by the number of action potentials generated in the burst.

The average single-spike IPSP amplitude was larger during presynaptic burst discharge than was the mean amplitude of single IPSPs activated at interspike frequencies of $\sim 1 \mathrm{~Hz}$ in all pairs tested $(n=11)$. These results confirm the presence of facilitation in the efficacy of the synaptic transmission from PGN to LGNd during high-frequency discharge (Fig. 4C,Da). The facilitation in the transmission by the burst discharge was again a function of the rate of action potential generation in that the average single-spike IPSP amplitude increased progressively with increasing rate of action potential generation (Fig. $4 C$ ). Even in one connected pair of cells in which single IPSPs after presynaptic action potentials at $1 \mathrm{~Hz}$ were barely detectable $(0.1-0.2$ $\mathrm{mV})$, the burst discharge of a presynaptic PGN cell evoked compound IPSPs of $\sim 3 \mathrm{mV}$, from which was calculated an average IPSP amplitude per single spike of $0.51 \mathrm{mV}$ (data not shown).

There was a weak $(r=-0.59 ; p=0.07)$ correlation between the amplitude of the single IPSP at low frequency versus the average facilitation during a burst discharge (Fig. 4Db). Thus, the amplitude of facilitation tended to be lowest in the pairs of cells that produced the largest single IPSPs. To address the question whether the efficacy of synaptic transmission from PGN to LGNd cells is modulated solely by the rate of presynaptic action potential generation or is also influenced by the mode of action potential generation (e.g., burst vs tonic), we compared for the two modes of action potential generation ( $n=4$ pairs) the amplitudes of compound IPSPs summated from a fixed number of presynaptic spikes (four to six among different pairs of cells). The resulting relationship between the amplitude of the compound IPSP and the rate of presynaptic spike discharge indicated that the large amplitude of IPSPs evoked by burst discharges is as predicted by the high frequency of tonic action potential generation in the presynaptic cell (Fig. $4 E, F$ ).

Changing the membrane potential of the thalamocortical neuron had significant effects on the response of these cells to the IPSP barrage (Fig. 5). At relatively hyperpolarized membrane potentials (e.g., Fig. $5 A,-72 \mathrm{mV}$ ), the activation of an IPSP by a burst of action potentials in a PGN neuron could result in a rebound low-threshold $\mathrm{Ca}^{2+}$ spike-mediated burst of action potentials. However, depolarization of the thalamocortical cell by as little as $3 \mathrm{mV}$ resulted in a substantial reduction in the amplitude or abolition of the rebound $\mathrm{Ca}^{2+}$ spike (Fig. $5 B,-69 \mathrm{mV}$ ). Further depolarization of the thalamocortical neuron into the tonic firing mode revealed that the activation of a burst of action potentials in the PGN neuron could generate a $20-50 \mathrm{msec}$ period of inhibition of tonic discharge, corresponding approximately to the duration of the PGN burst discharge (Fig. $5 C$ ).

\section{Single PGN cells can activate both $\mathrm{GABA}_{A}$ and $\mathrm{GABA}_{B}$ receptor-mediated IPSPS}

We have demonstrated previously that activation of single PGN cells can activate both $\mathrm{GABA}_{\mathrm{A}}$ and $\mathrm{GABA}_{\mathrm{B}}$ receptor-mediated IPSPs in thalamocortical cells, depending on the pattern of presynaptic action potential generation (Fig. 6) (see Kim et al., 1997). Here we addressed the question, does the activation of burst discharges activate both $\mathrm{GABA}_{\mathrm{A}}$ and $\mathrm{GABA}_{\mathrm{B}}$ receptormediated IPSPs in normal solution? This question was difficult to address in current-clamp recordings, because the activation of a large $\mathrm{GABA}_{\mathrm{A}}$ receptor-mediated IPSP was typically associated with a rebound low-threshold $\mathrm{Ca}^{2+}$ spike during the time period in which the $\mathrm{GABA}_{\mathrm{B}}$ receptor-mediated IPSP was expected to be prominent (Fig. 6A). However, comparing the amplitude and time course of the evoked IPSP as $\mathrm{GABA}_{\mathrm{A}}$ receptors were gradually blocked with bath application of bicuculline methiodide revealed that the slow IPSP, mediated by $\mathrm{GABA}_{\mathrm{B}}$ receptors (Kim et al., 1997), may make a small contribution to the late portions of normal IPSPs (Fig. 6B). Thus, the block of $\mathrm{GABA}_{\mathrm{A}}$ receptors revealed a slow IPSP that overlapped with the late portions of the normal IPSP and therefore may have contributed to this (Fig. $6 B)$. However, in the presence of bicuculline methiodide, the number of action potentials generated by the PGN cell with each burst increased significantly, in part because of disinhibition from neighboring PGN cells (Sanchez-Vives et al., 1997) as well as the block of $\mathrm{Ca}^{2+}$-activated $\mathrm{K}^{+}$currents (Johnson and Seutin, 1997; Seutin et al., 1997). Therefore, the amplitude of the $\mathrm{GABA}_{\mathrm{B}}$ IPSP remaining after application of bicuculline methiodide is considerably larger than would be expected if the number of action potentials in the presynaptic cell was held constant (e.g., see Fig. 6A).

The convergence and divergence of connections between populations of PGN and LGNd cells underlie the propagation and synchronization of spontaneous spindle waves in ferret LGNd slices in vitro (Kim et al., 1995). To obtain a measure of the convergence from PGN cells to thalamocortical neurons, we com- 

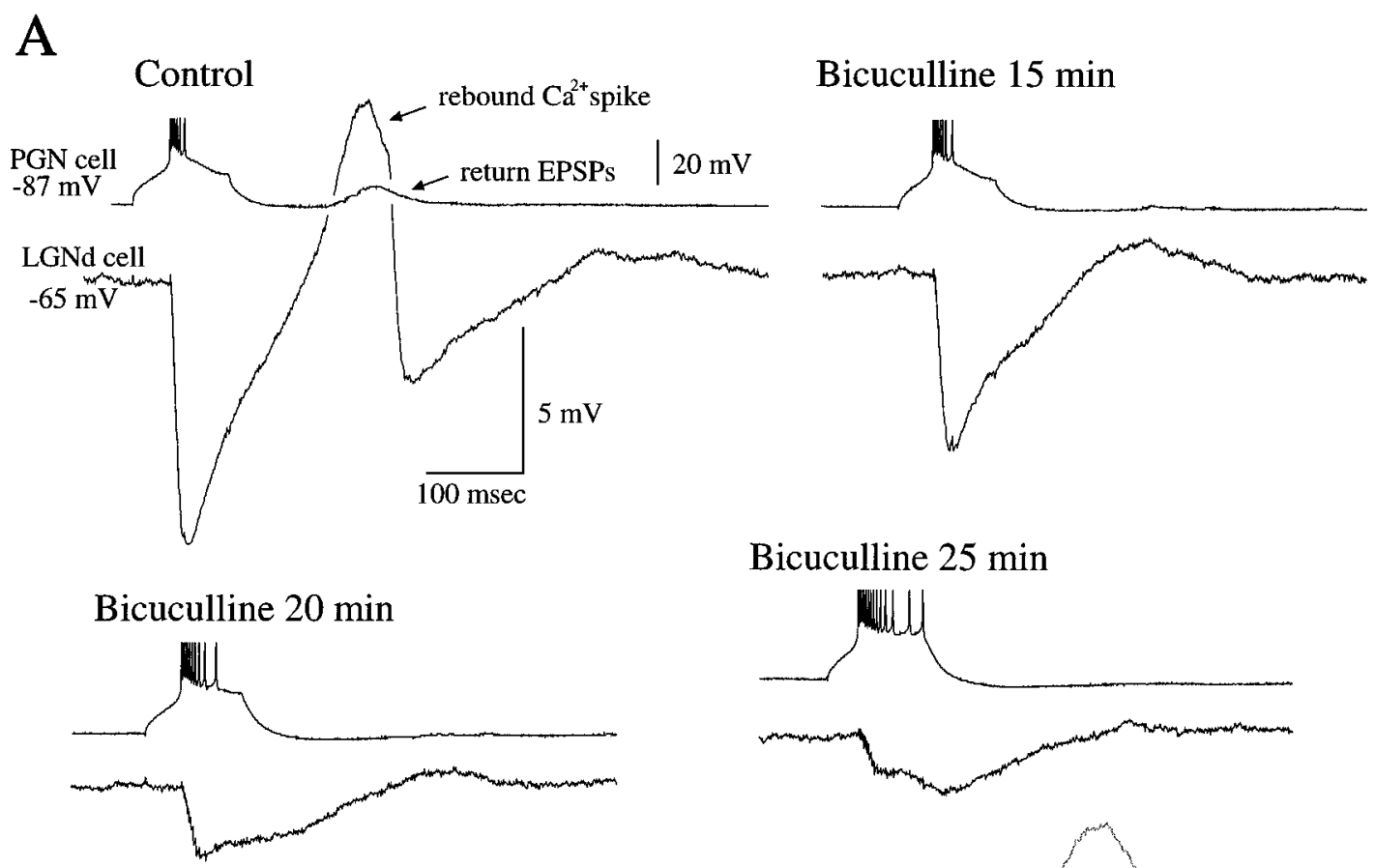

Bicuculline $25 \mathrm{~min}$
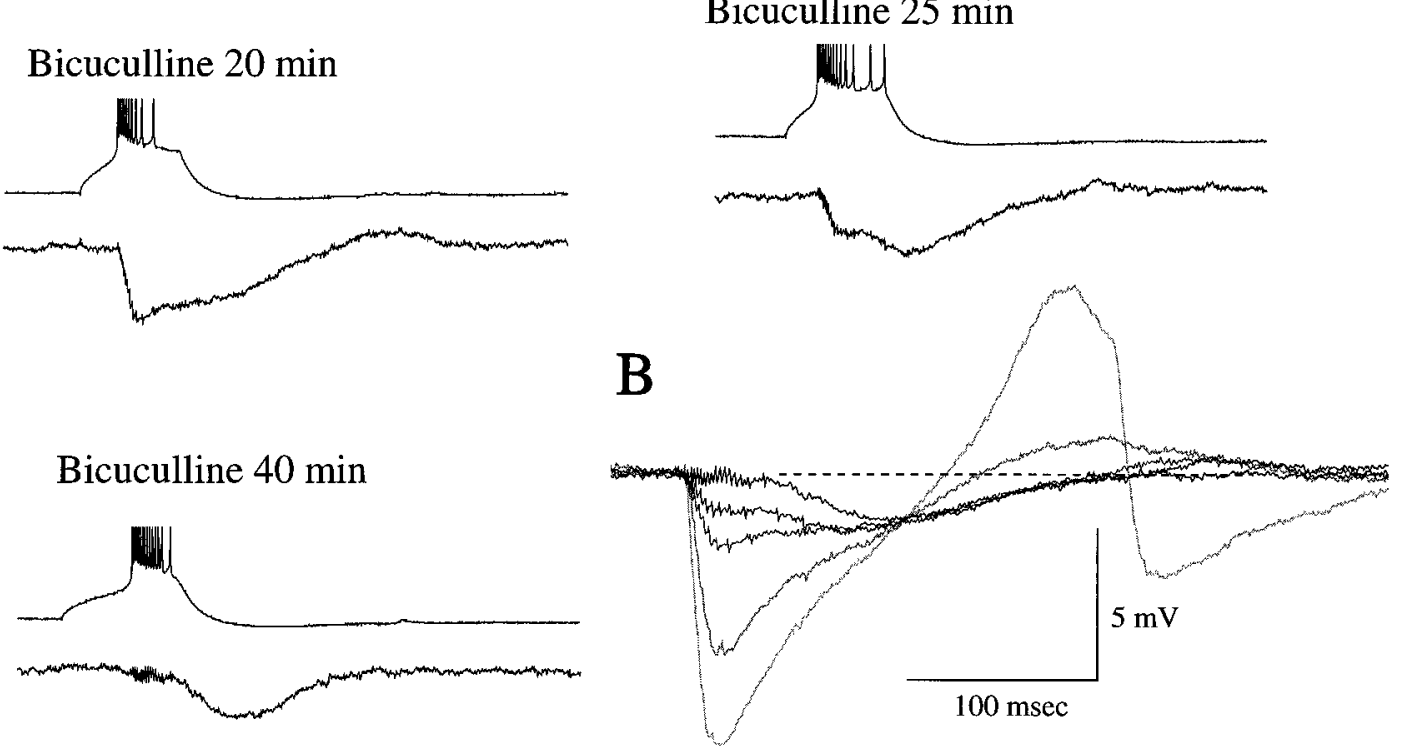

Figure 6. The progressive block of GABA receptors reveals the contribution of $\mathrm{GABA}_{\mathrm{B}}$ receptor activation. $A$, In control, the burst discharge of the presynaptic PGN cell results in a large IPSP and the activation of a rebound low-threshold calcium spike. The temporal development of this rebound calcium spike overlaps and conceals the activation of the $\mathrm{GABA}_{\mathrm{B}}$ receptor-mediated IPSP. The bath infusion of bicuculline methiodide (100 $\left.\mu \mathrm{M}\right)$ gradually blocks the fast, $\mathrm{GABA}_{\mathrm{A}}$ receptor-mediated component of the evoked IPSP, and this also results in a loss of the rebound low-threshold Ca ${ }^{2+}$ spike. After 20-25 min, both GABA $A_{A}$ and $G_{A B A}$ receptor-mediated IPSPs are activated after a single burst in the PGN cell. After 40 min, bicuculline infusion completely blocks the $\mathrm{GABA}_{\mathrm{A}}$ receptor-mediated IPSP and unveils the pure $\mathrm{GABA}_{\mathrm{B}}$ receptor-mediated IPSPs. $B$, Overlap of the responses in $A$ is shown. Note that the number of action potentials generated by the PGN cell also increased in the presence of bicuculline.

pared the amplitude of IPSPs resulting from a single burst in a presynaptic PGN cell with that of barrages of IPSPs recorded during the spontaneous generation of spindle oscillations (Fig. 7).

Whereas the induction of a single burst in a presynaptic PGN cell activated postsynaptic IPSPs of $\sim 2-11 \mathrm{mV}$ in amplitude, the same postsynaptic LGNd cell received barrages of IPSPs of $\sim 9-24 \mathrm{mV}$ in amplitude during spontaneous generation of spindle oscillations. The average amplitude of IPSPs induced by burst firing in PGN cells was $4.4 \pm 2.5 \mathrm{mV}$, whereas the average peak amplitude of IPSPs in the same thalamocortical neurons during spindle wave generation was $15.5 \pm 3.6 \mathrm{mV}$ ( $n=30$ pairs).

During the generation of spindle oscillations, PGN cells generate repetitive burst discharges of action potentials at an interburst frequency of 6-10 Hz. Here we examined how this repetitive burst discharge may affect synaptic transmission between PGN and LGNd cells. When PGN cells were induced to generate repetitive bursts of action potentials at interburst frequencies $>1$ $\mathrm{Hz}$, the second barrage of IPSPs decreased in amplitude in comparison with the first, whereas relatively little change in amplitude was observed between the second and the subsequent barrages of IPSPs whether they were mediated by GABA $_{\mathrm{A}}$ (Fig. $8 A ; n=4$ pairs) or $\mathrm{GABA}_{\mathrm{B}}$ (Fig. $8 B$ ) receptors.

\section{Thalamocortical excitation of perigeniculate neurons}

The probability of obtaining monosynaptic connections from a thalamocortical neuron to a PGN cell was significantly less than that in the other direction, presumably because of the markedly less dense axon collaterals formed in the PGN by thalamocortical cells in comparison with those formed in the LGNd by PGN cells (Ferster and LeVay, 1978; Friedlander et al., 1981; Stanford et al., 1983; Kim et al., 1997). Activation of a single action potential in a presynaptic thalamocortical neuron resulted in the activation of a $0.5-2.0 \mathrm{mV}$ amplitude EPSP, with a duration of 20-120 msec, in the PGN neuron at -70 to $-80 \mathrm{mV}$ (Fig. 9; $n=5$ ). The generation of repetitive action potentials at frequencies greater than $\sim 10-50 \mathrm{~Hz}$ resulted in temporal summation of EPSPs in the recipient PGN cell (Fig. 9). However, in contrast to IPSPs gen- 
Aa
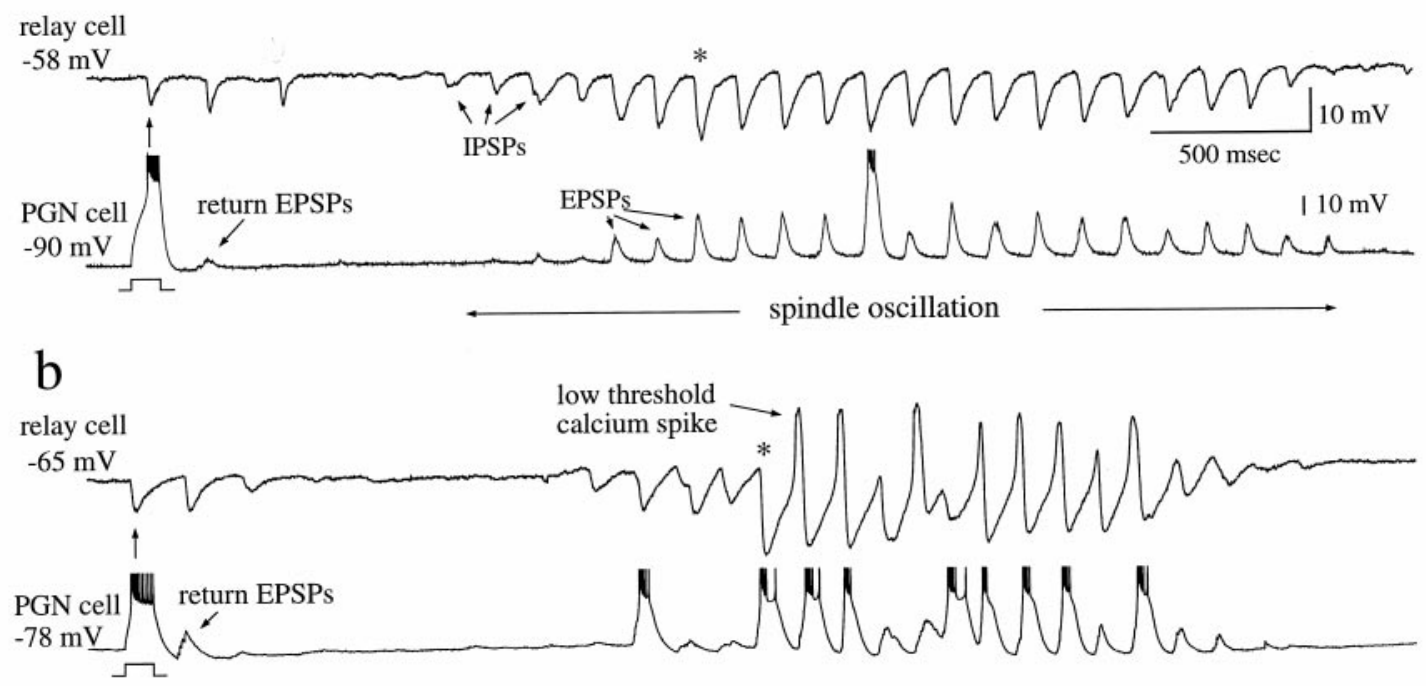

$\mathrm{Ba}$
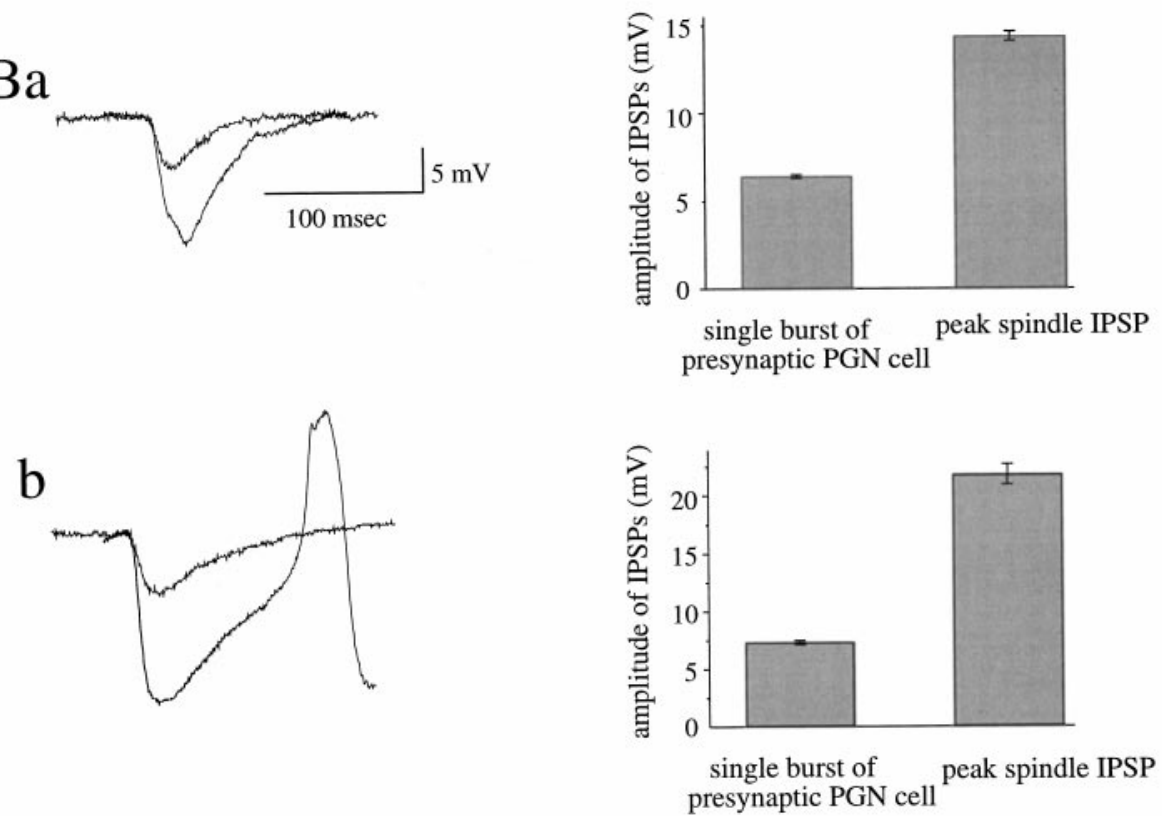

Figure 7. Degree of convergence of PGN neurons onto single thalamocortical cells. $A$, Induction of a burst discharge in presynaptic PGN cells in two connected pairs $\sim 1-2 \mathrm{sec}$ before the arrival of a spindle wave initiated three cycles of IPSPs in the recipient thalamocortical cell via divergent and convergent connections between the two population of neurons. During the generation of a spindle wave, the same thalamocortical cells received a barrage of IPSPs that grew in amplitude, resulting from recruitment of convergent PGN cells into the oscillation. $B$, Overlay of a summated IPSP from the burst discharge of a single presynaptic PGN cell with the peak IPSP (* in $A$ ) generated during spindle oscillation reveals a three- to fourfold increase in IPSP amplitude during the spindle oscillation. Because of the nonlinear nature of the summation of IPSPs from a population of convergent PGN cells, especially as summated IPSPs reach the reversal potential, this ratio will underestimate the degree of convergence. Data obtained from two different cell pairs are shown. Pairs in $A a$ and $A b$ are shown in $B a$ and $B b$.

erated in thalamocortical cells, single-spike EPSPs in PGN neurons did not exhibit facilitation at any frequency and in fact typically decreased in amplitude with the generation of each action potential, particularly at frequencies greater than $\sim 100 \mathrm{~Hz}$ (Figs. 9A, $C, 10$ ).

The activation of a burst-induced barrage of EPSPs in a PGN neuron at a membrane potential of $-75 \mathrm{mV}$ could be subthreshold for the activation of a low-threshold $\mathrm{Ca}^{2+}$ spike in the PGN cell (Fig. 9D). Depolarization of the PGN neuron to $-67 \mathrm{mV}$ resulted in the EPSP barrage activating a low-threshold $\mathrm{Ca}^{2+}$ spike and burst of action potentials in this cell. Remarkably, in the pair illustrated in Figure 9D, the burst of activity in the PGN cell induced a barrage of IPSPs in the thalamocortical cell, indicating that these two cells were monosynaptically connected in both directions, forming a disynaptic loop between the PGN and LGNd. The latency from generation of the initial action potential in a burst in the PGN cell to the onset of the IPSP in the LGNd cell was $1.0 \mathrm{msec}( \pm 0.2 \mathrm{msec} ; n=20)$. In addition, the "return IPSP" onset varied precisely with the onset latency for the burst of action potentials in the recorded PGN cell $(r=1.0)$, and when the PGN cell did not discharge, there was no return IPSP in the thalamocortical neuron. These results confirm that these two cells 


\section{A $6 \mathrm{~Hz}$ interburst discharge of PGN cell}

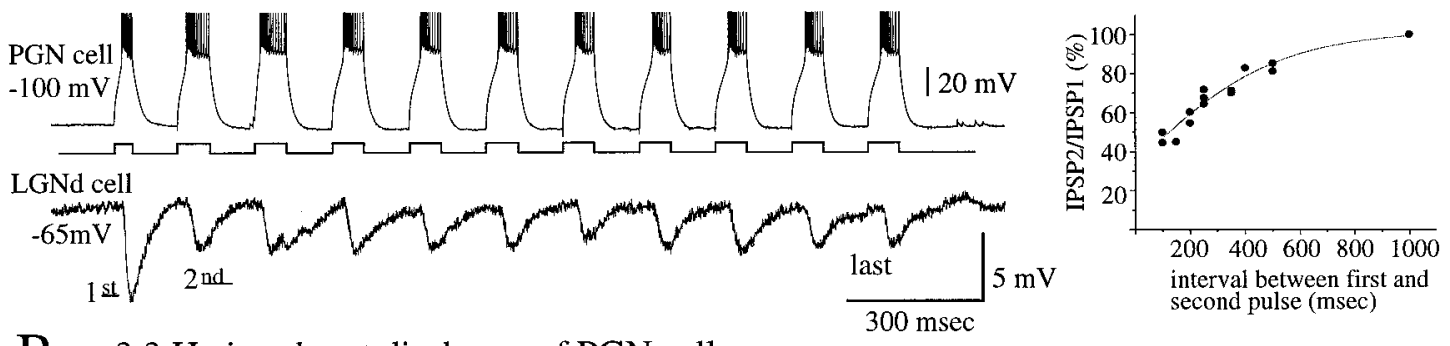

B $\quad 3.3 \mathrm{~Hz}$ interburst discharge of PGN cell in the presence of bicuculline

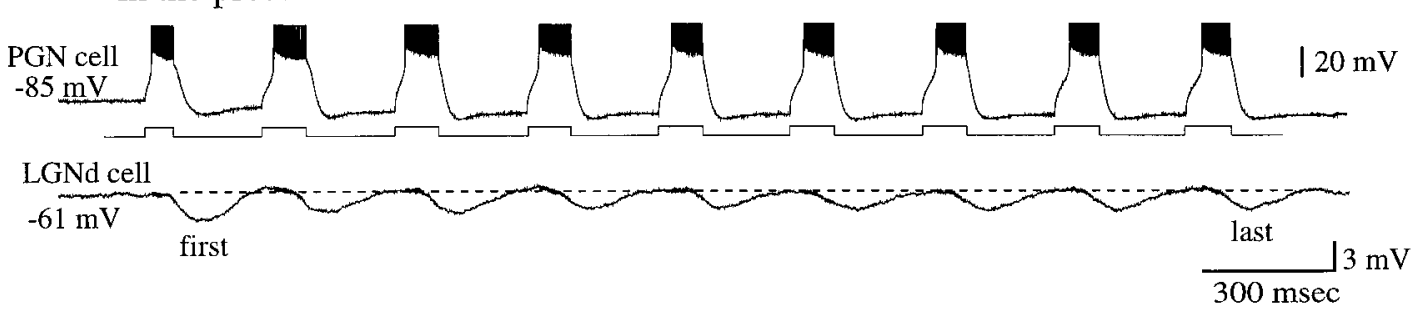

C $7 \mathrm{~Hz}$ interburst discharge of relay cell
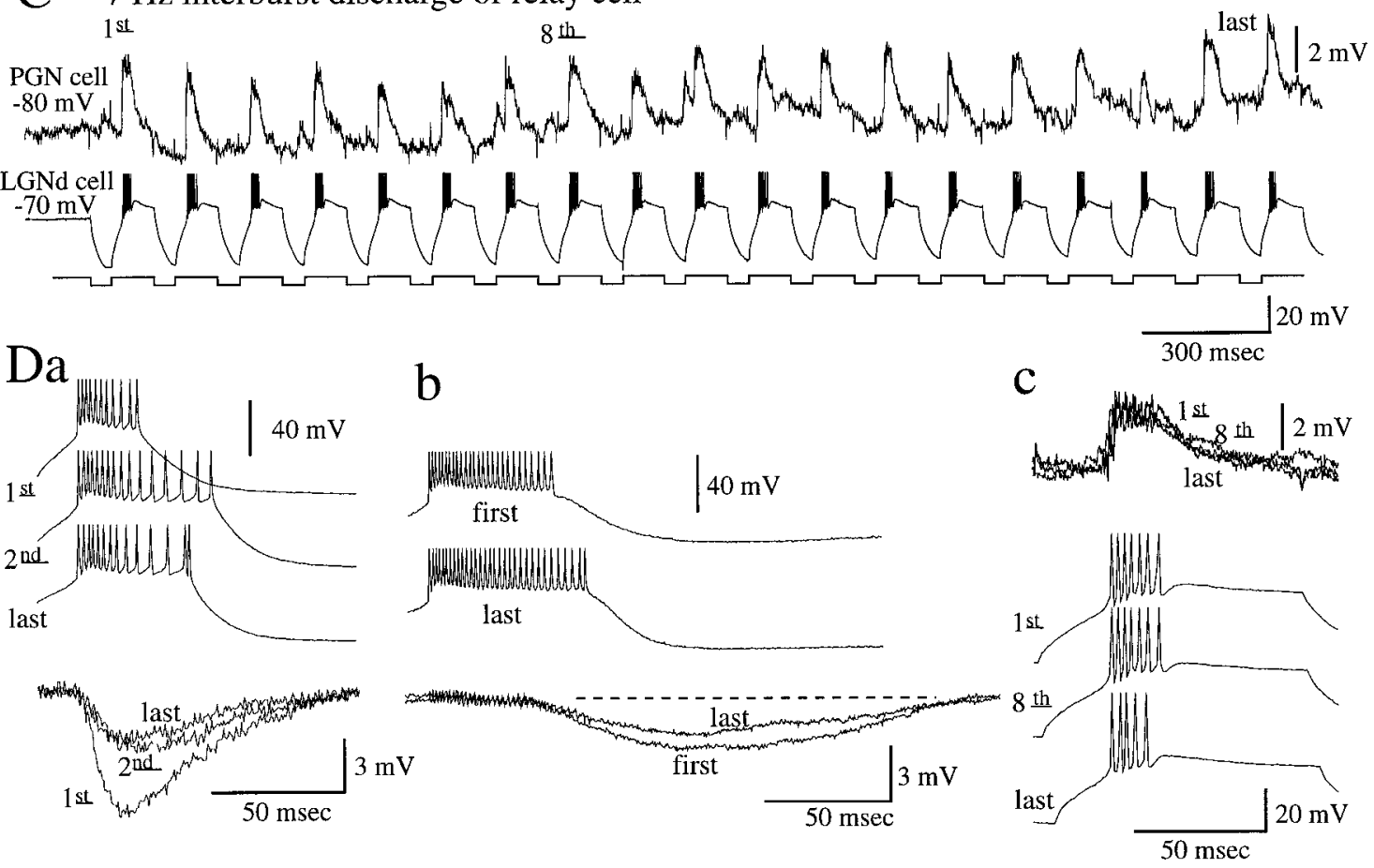

Figure 8. Effects of repetitive discharge of the presynaptic neuron on synaptic transmission between thalamocortical and PGN neurons. $A$, Repetitive burst discharges in a PGN neuron result in IPSP barrages that decrease in amplitude, particularly between the first and second barrages, despite increases in the number of action potentials generated by the presynaptic neuron. The depression in amplitude of the second barrage of IPSPs begins to occur at interburst frequencies $>1 \mathrm{~Hz}$, with the amplitude reduced by one-half at $\sim 5 \mathrm{~Hz}$. $B$, In the presence of bicuculline, GABA $\mathrm{B}_{\mathrm{B}}$ receptor-mediated IPSPs also exhibit decrements in amplitude between the first and second slow IPSPs. $C$, Repetitive burst firing in a thalamocortical cell, induced by the intracellular injection of hyperpolarizing current pulses, results in barrages of EPSPs in a PGN neuron. These EPSP barrages do not change markedly in peak amplitude with repetitive activation. $D$, Overlap of the indicated IPSP and EPSP barrages is illustrated. Sharp, spike-like events above the EPSP barrages are capacitance-coupling artifacts.

are monosynaptically connected in both directions. Depolarization of the PGN neuron such that it was now in the tonic firing mode dramatically reduced the excitatory effect of the barrage of EPSPs such that now they generated only one extra action potential in the PGN cell (Fig. 9D, $-55 \mathrm{mV}$ ).

During the generation of spindle waves, each PGN cell received from a population of thalamocortical cells EPSP barrages that grew in amplitude eventually to activate low-threshold calcium-mediated burst discharges (Fig. 11A). The peak amplitude of these EPSP barrages reached 16-24 mV. Single-burst discharges of presynaptic thalamocortical cells activated EPSP barrages that were an average of $3.0 \pm 1.0 \mathrm{mV}(n=4)$ in recipient PGN cells, suggesting a five- to eightfold increase in the peak amplitude of EPSP barrages during spindle oscillation, because of 


\section{A Tonic Firing}
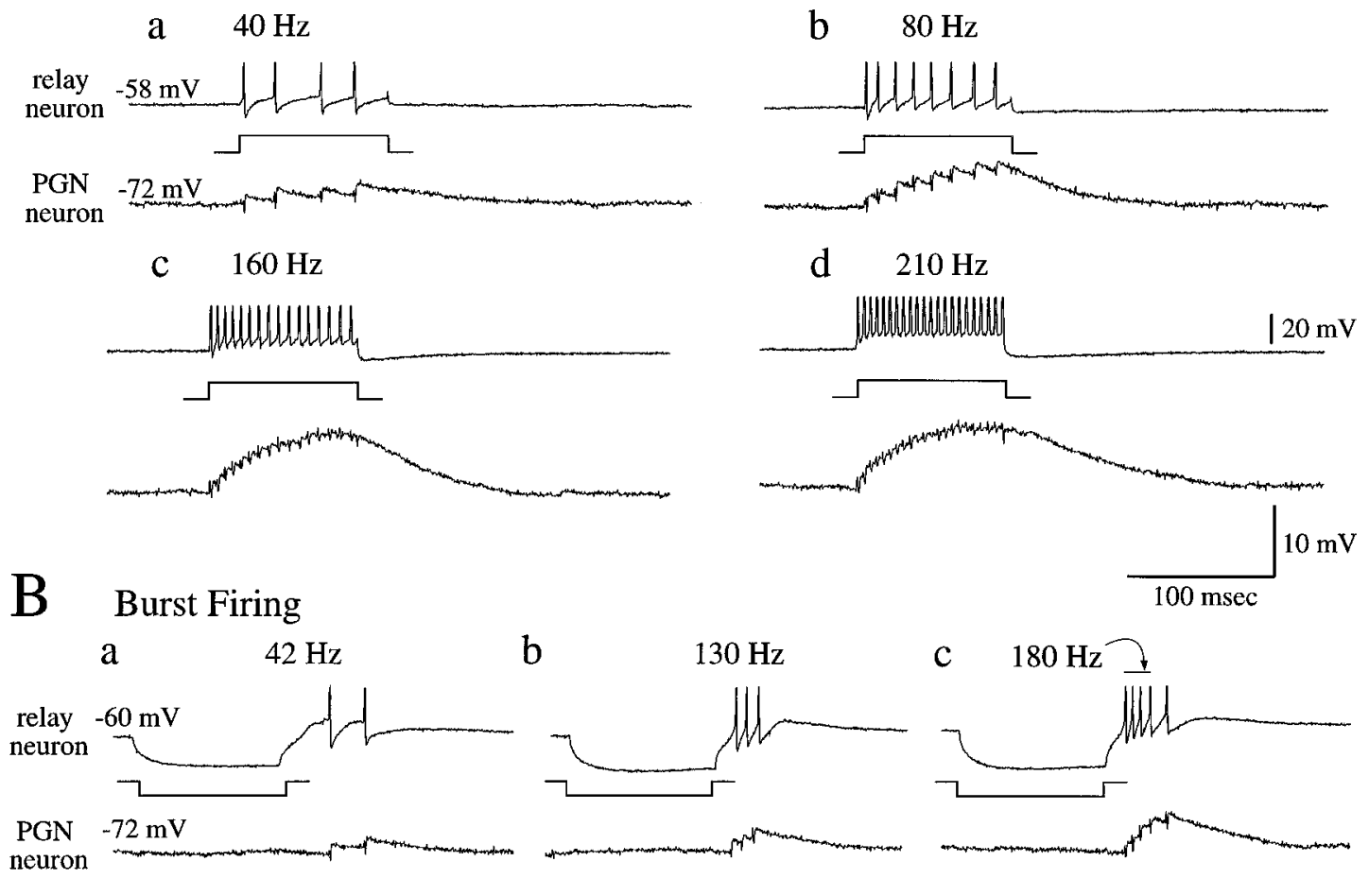

\section{Presynaptic Tonic}

\section{Presynaptic Burst}
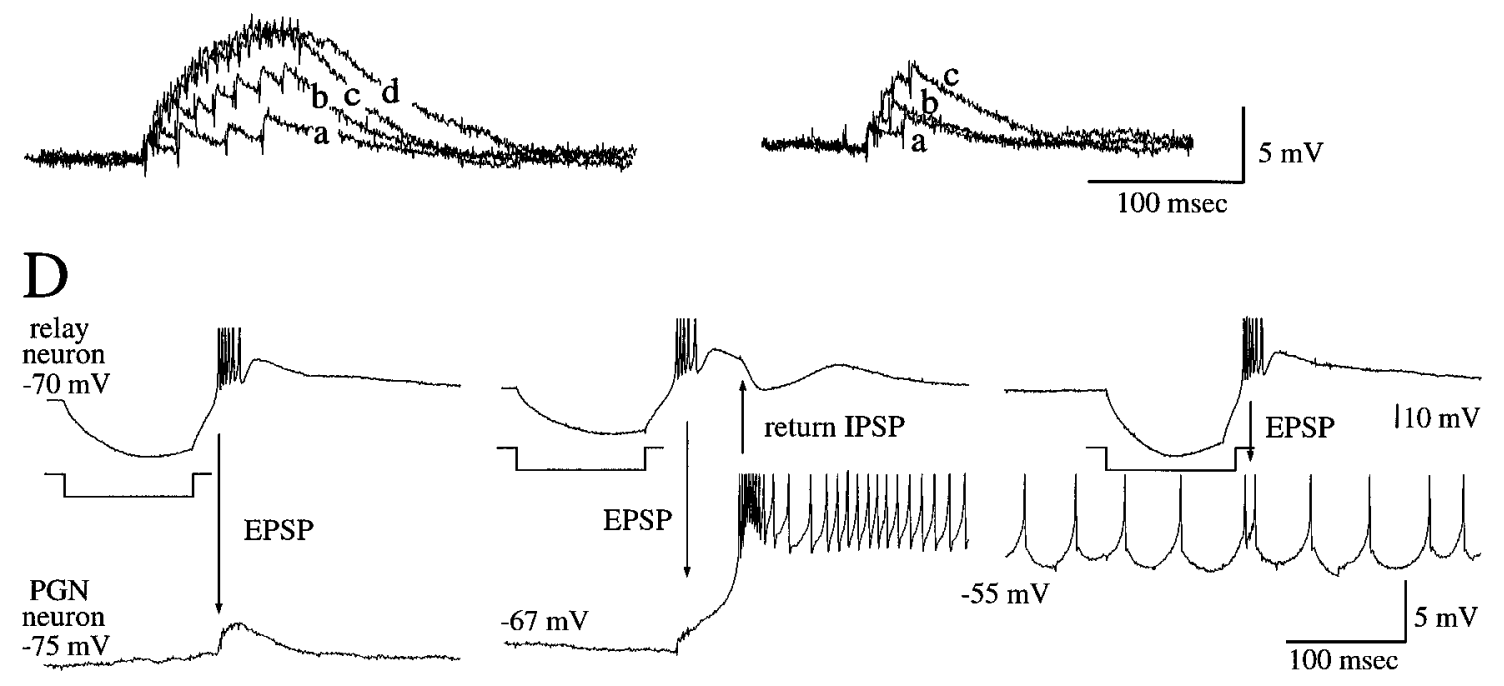

Figure 9. Properties of monosynaptic connections between thalamocortical neurons and recipient PGN cells. $A$, Activation of tonic firing in a thalamocortical neuron results in a train of EPSPs in the PGN neuron. Increasing the frequency of action potential generation in the thalamocortical neuron results in temporal summation of these EPSP barrages. Note that the EPSP barrages reach a plateau and do not show facilitation. $B$, Activation of bursts of action potentials in the thalamocortical neuron results in summated barrages of EPSPs in the PGN cell. $C$, Overlays of postsynaptic recordings in $A$ and $B$ are shown. $D$, Changing the membrane potential of the postsynaptic neuron alters the functional effect of the EPSP barrage. Depolarization of the PGN neuron from -75 to $-67 \mathrm{mV}$ results in the EPSP barrage (generated by a burst of action potentials in the thalamocortical cell) reaching threshold for the activation of a low-threshold $\mathrm{Ca}^{2+}$ spike and triggering a burst of action potentials in the PGN cell. Further depolarization of the PGN neuron into the single-spike firing mode dramatically reduces the excitatory effect of the EPSP barrage such that it generates only one additional action potential.

the synchronized discharge of convergent thalamocortical cells onto single PGN cells (Fig. 11).

Repetitive activation of burst discharges at 5-9 $\mathrm{Hz}$ resulted in the generation of repetitive barrages of EPSPs in PGN neurons
(Fig. 8C). In contrast to IPSP barrages between PGN and thalamocortical cells, these EPSP barrages did not exhibit significant decreases in peak amplitude with repetitive activation (Fig. 8C,D). 

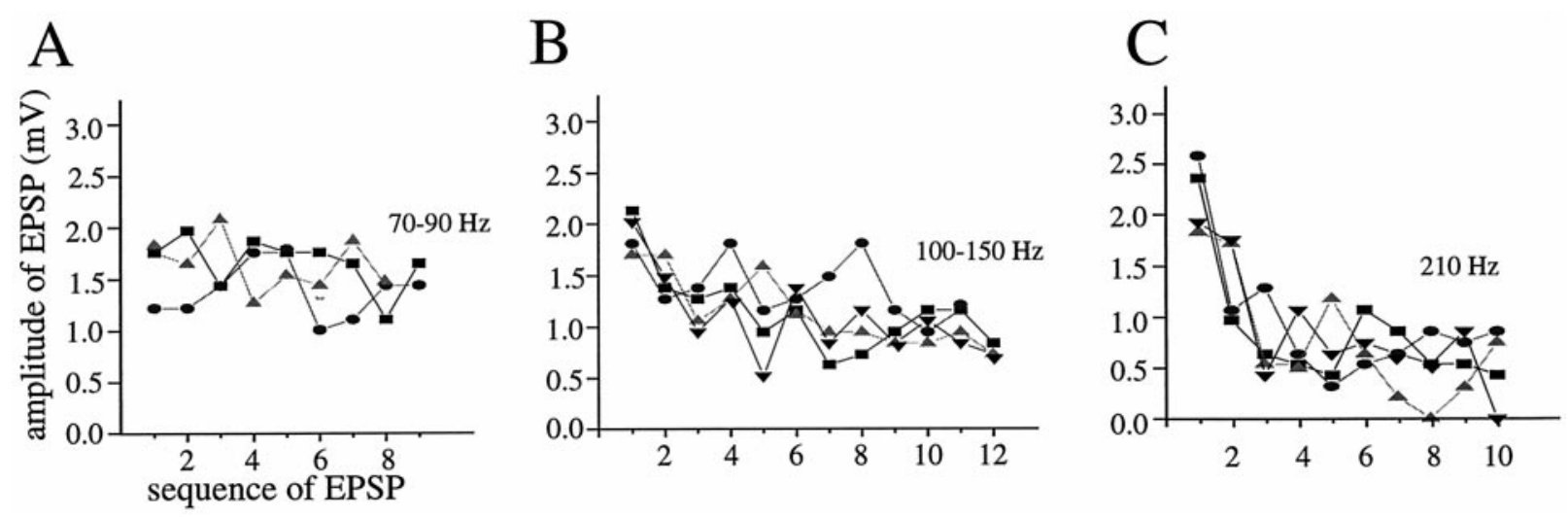

Figure 10. The amplitude of single-spike EPSPs in the postsynaptic PGN cell decreases during the generation of a high-frequency train of action potentials in the presynaptic thalamocortical cell. $A$, At low-frequency discharge rates $(70-90 \mathrm{~Hz})$, EPSP amplitudes are relatively stable. $B$, At higher frequency $(100-150 \mathrm{~Hz})$ rates of presynaptic discharge, the EPSPs exhibit a steady decrement in amplitude. $C$, The EPSPs during an increased intensity of presynaptic discharge $(210 \mathrm{~Hz})$ decrease markedly after the first EPSP.

\section{DISCUSSION}

Our results demonstrate that synaptic transmission from PGN to LGNd cells is highly dynamic, depending on the pattern of activity in the presynaptic PGN cell. The amplitude of individual IPSPs generated by action potentials in the PGN cell may be either larger or smaller than that of the previous IPSPs, depending on the frequency of action potential activity and the number of action potentials generated in the immediate past. Recent investigations of synaptic transmission between hippocampal pyramidal cells have demonstrated that the probability of transmitter release is dependent on whether or not the preceding action potential in the train results in the release of neurotransmitter (Dobrunz and Stevens, 1997; Murthy et al., 1997). If the preceding action potential did not result in the release of neurotransmitter, then the probability of release in the following action potential is substantially increased, whereas if the preceding action potential did result in neurotransmitter release, it was decreased. These results are consistent with a "priming" effect of $\mathrm{Ca}^{2+}$ entry in the presynaptic terminal coupled together with another mechanism that limits the frequency response of neurotransmitter release (such as the number of vesicles available in the readily releasable pool) (Dobrunz and Stevens, 1997).

The generation of action potentials in PGN cells at frequencies greater than $\sim 100 \mathrm{~Hz}$ resulted in the strong facilitation of synaptic transmission during the initial three to five IPSPs (Figs. 1, 3, 4). Presumably, this increase in IPSP amplitude resulted from an increase in release of transmitter, perhaps via a $\mathrm{Ca}^{2+}$-dependent mechanism (e.g., Magleby, 1987; Zucker, 1993), although this remains to be investigated. Functionally, this strong facilitation results in especially large IPSP amplitudes in response to the generation of bursts of action potentials (e.g., Figs. 1, 4). Highfrequency burst generation in thalamic reticular neurons occurs primarily during periods of non-rapid-eye-movement (non-REM) sleep, and each burst is typically preceded by a period of reduced action potential discharge or silence (Mukhametov et al., 1970a,b; Domich et al., 1986; Steriade et al., 1986). In the awake and attentive animal, thalamic reticular neurons typically discharge in the tonic discharge mode at frequencies considerably $<100 \mathrm{~Hz}$, although the possibility that these cells may fire brief bursts of high-frequency activity in particular behavioral situations remains to be investigated. The generation of large IPSPs is particularly efficacious in activating rebound low-threshold $\mathrm{Ca}^{2+}$ spikes in thalamocortical neurons (see Fig. 5), which seem to be critical to the generation of at least some forms of synchronized thalamocortical rhythms during non-REM sleep (Lee and McCormick, 1996, 1997).

In addition to short-term facilitation and depression, the repetitive activation of bursts in PGN cells also exhibited depression of synaptic transmission between the first and second response that occurred at frequencies between 1 and $8 \mathrm{~Hz}$ and that persisted for $\sim 1 \sec$ (Fig. $8 A, B$ ). A similar frequency-dependent depression of GABAergic synaptic transmission has been demonstrated in pyramidal cells of the hippocampus and cerebral cortex (Deisz and Prince, 1989; Nathan and Lambert, 1991; Davies and Collingridge, 1993), in which both postsynaptic and presynaptic mechanisms are involved. The postsynaptic mechanisms include a decrease in the driving force because of the intracellular accumulation of chloride ions (Thompson et al., 1993), the desensitization of $\mathrm{GABA}_{\mathrm{A}}$ receptors (Huguenard and Alger, 1986; Frosch et al., 1992), and perhaps the modulation of conductance through $\mathrm{GABA}_{\mathrm{A}}$ receptors by corelease of various transmitters (Scharfman and Schwartzkroin, 1989), whereas the presynaptic mechanisms include autoinhibition through presynaptic $\mathrm{GABA}_{\mathrm{B}}$ receptors (Deisz and Prince, 1989; Otis and Mody, 1992; Davies and Collingridge, 1993; Mott et al., 1993; Uhlrich and Huguenard, 1996) and the transient depletion of the transmitters in the presynaptic terminals (Dobrunz and Stevens, 1997). It remains to be determined how each of these cellular mechanisms contributes to synaptic depression at PGN synapses onto thalamocortical cells.

\section{Properties of thalamocortical synapses onto PGN cells}

Activation of an action potential in a single thalamocortical cell resulted in EPSPs that are $0.7-2.0 \mathrm{mV}$ in amplitude in the postsynaptic PGN neuron. This EPSP amplitude is similar to that for the influence of pyramidal cells in the hippocampus and cerebral cortex onto local interneurons (Miles, 1990; Gulyás et al., 1993; Thomson et al., 1993a; Debanne et al., 1995), which, in at least some cases, is mediated by a single release site (Gulyás et al., 1993).

In contrast to our observations on the PGN to thalamocortical cell synapse, we did not observe facilitation in the postsynaptic EPSPs generated by thalamocortical cells in PGN neurons, even at high frequencies. With repetitive activation, thalamocortical EPSPs exhibited pronounced decrements in amplitude (Figs. 9, 


\section{Aa}

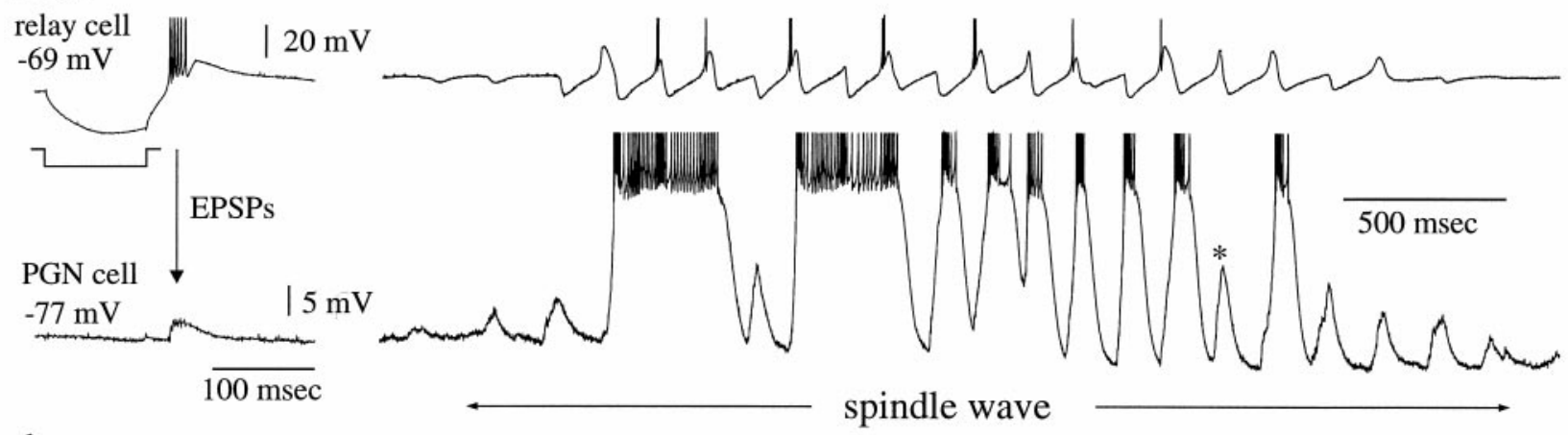

b
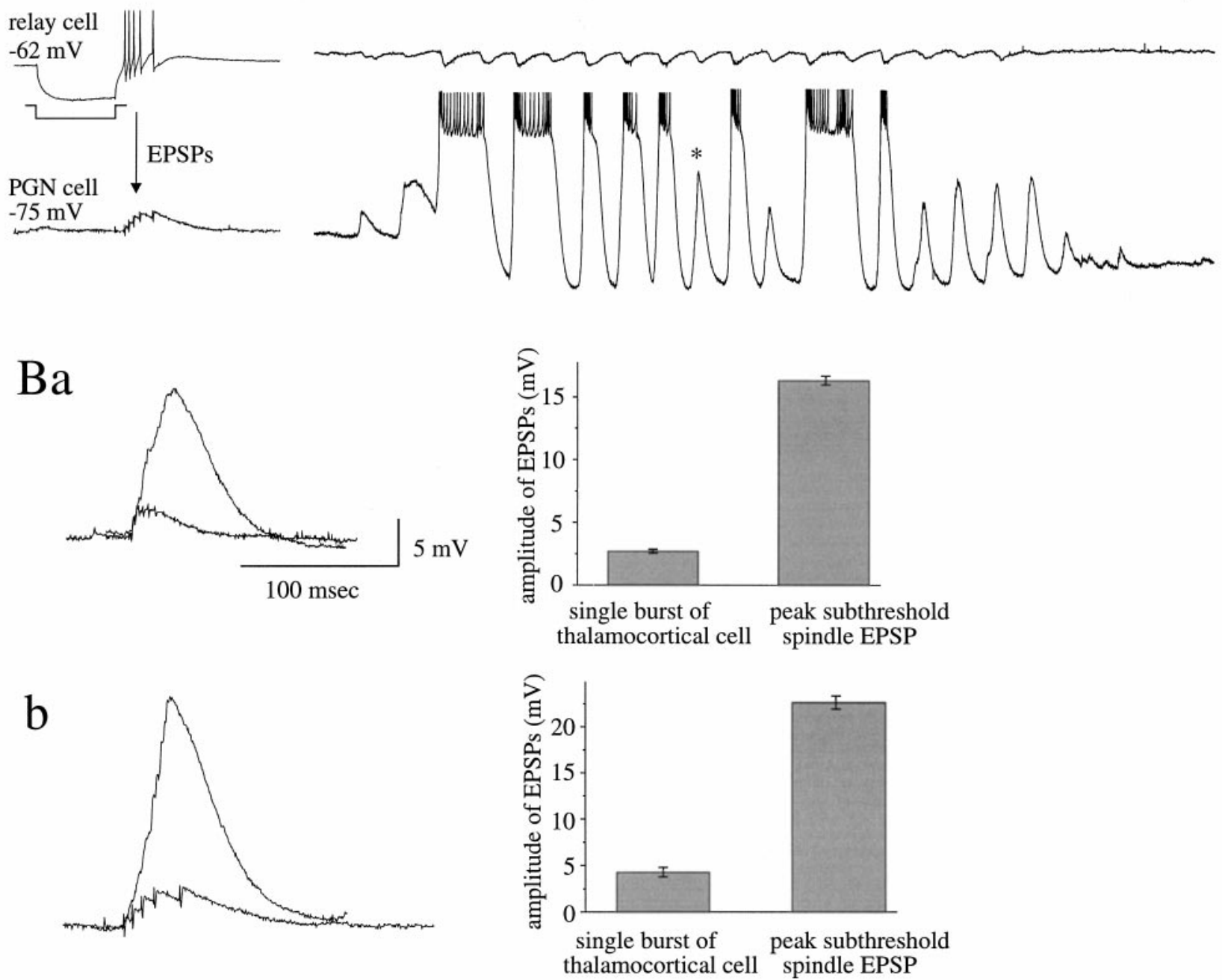

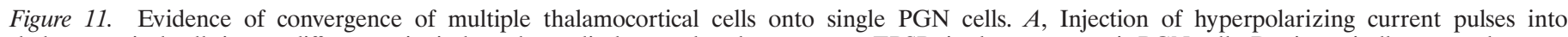

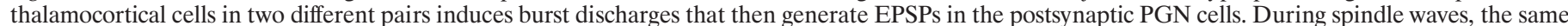

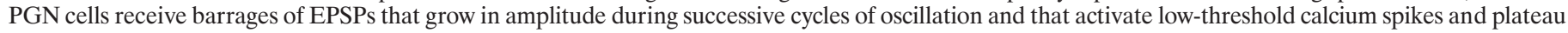

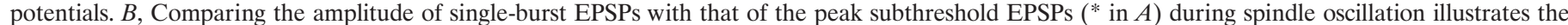

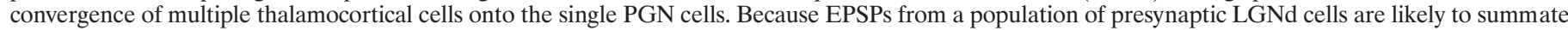

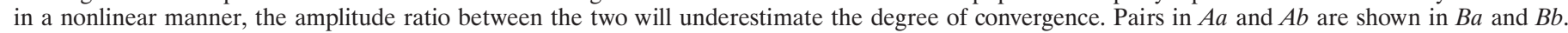

10), which may result from both pre- and postsynaptic influences such as the saturation of postsynaptic receptors (Tang et al., 1994; Tong and Jahr, 1994), desensitization of AMPA/kainate receptors (Trussell and Fischbach, 1989; Colquhoun et al., 1992), or a decrease in the release of neurotransmitter with each action potential (Dobrunz and Stevens, 1997). However, repetitive burst firing in thalamocortical cells resulted in a relatively steady amplitude of EPSP barrages in the postsynaptic PGN neuron (Fig. 
$8 C, D)$, suggesting that the mechanisms that decrement EPSP amplitude do not have low-frequency components.

\section{Functional properties of burst and tonic mode}

The burst and lower frequency tonic firing modes of action potential generation seem to differ in their effects on synaptic transmission in the thalamus attributable in part to the temporal summation of PSPs, to the temporally isolated nature of burst discharges, and, in the case of PGN to thalamocortical cell synapses, to facilitation at high frequencies. The first and last differences result from the high frequencies $(300-500 \mathrm{~Hz})$ of action potential discharge associated with burst discharges. Thus, if a quiescent PGN neuron were to generate action potentials in the tonic firing mode at a rate that was comparable with that of burst discharges, then similar levels of summation and facilitation are expected to occur in the postsynaptic response. Presumably, the presynaptic terminals formed by PGN axons experience only the pattern of action potential generation arriving at these terminals and are not influenced by the mechanisms by which these action potential patterns are generated at the soma (e.g., via a low threshold $\mathrm{Ca}^{2+}$ spike or tonic discharge). However, if the PGN neuron generates a high-frequency tonic discharge in the midst of ongoing tonic activity, then the resulting IPSP should be smaller than that during an isolated burst discharge because of large decreases in synaptic facilitation (e.g., Fig. 3) and postsynaptic response (Fig. 8A,B). Therefore, isolated, high-frequency burst discharges are particularly effective in activating large IPSPs in postsynaptic thalamocortical cells. Although it has not been specifically addressed, it is widely assumed that PGN neurons generate high-frequency discharges primarily, or exclusively, via the activation of low-threshold $\mathrm{Ca}^{2+}$ spikes and that the tonic mode of action potential generation is associated with activity in the frequency range of $0-200 \mathrm{~Hz}$ (Mukhametov et al., 1970a,b; Steriade et al., 1986). If true, then these differences in frequency of presynaptic action potential generation will have marked and important effects on transmission between the PGN and thalamocortical cells in the LGNd. For example, burst discharges in PGN cells result in postsynaptic IPSPs in thalamocortical cells that are often large enough to result in the generation of a rebound low-threshold $\mathrm{Ca}^{2+}$ spike. In contrast, in the tonic firing mode, at frequencies of $0-100 \mathrm{~Hz}$, PGN cells generated relatively small $(<2 \mathrm{mV})$ IPSPs in thalamocortical cells and therefore were not able to generate rebound low-threshold $\mathrm{Ca}^{2+}$ spikes. In relatively rare cases, the activation of as few as two or three action potentials at $300-400 \mathrm{~Hz}$ in a PGN neuron can generate "return EPSPs," presumably resulting from the activation of lowthreshold $\mathrm{Ca}^{2+}$ spikes in thalamocortical cells (Bal et al., 1995b).

As we have reported previously for spindle wave-associated IPSPs, the IPSPs activated by single PGN cells seem to be mediated almost entirely via the activation of $\mathrm{GABA}_{\mathrm{A}}$ receptors. After the block of $\mathrm{GABA}_{\mathrm{A}}$ receptors and strong activation of the PGN cell, we found a small $(1-3 \mathrm{mV})$ residual slow IPSP that is mediated by $\mathrm{GABA}_{\mathrm{B}}$ receptors (e.g., Fig. 6) (see also Kim et al., 1997). This small amplitude for the single cell-induced $\mathrm{GABA}_{\mathrm{B}}$ IPSP contrasts with the ability of the activation of the PGN to generate large $(10-15 \mathrm{mV}) \mathrm{GABA}_{\mathrm{B}}$ receptor-mediated IPSPs during the generation of the bicuculline-induced paroxysmal oscillation (Bal et al., 1995a,b) or with the activation of the PGN with extracellular application of glutamate (Sanchez-Vives et al., 1997). These results suggest that several PGN cells need to discharge in synchrony to generate a postsynaptic $\mathrm{GABA}_{\mathrm{B}}$ receptor-mediated IPSP that is large enough to result in the rebound generation of low-threshold $\mathrm{Ca}^{2+}$ spikes. Indeed, we have found that return EPSPs from the activation of a single PGN cell are completely abolished after the block of $\mathrm{GABA}_{\mathrm{A}}$ receptors (Kim et al., 1995). In addition to the additive nature of several PGN cells converging onto single thalamocortical neurons, it is also possible that the requirement for several PGN cells to discharge to generate large $\mathrm{GABA}_{\mathrm{B}}$ receptor-mediated IPSPs results from an extrasynaptic location of these receptors (Isaacson et al., 1993; Mody et al., 1994) or from the properties of G-protein channel coupling (see Destexhe and Sejnowski, 1995). Applications of GABA to hippocampal pyramidal cells reveal that the activation of $\mathrm{GABA}_{\mathrm{B}}$ receptor-mediated increases in $\mathrm{K}^{+}$conductance actually requires a lower dose of GABA than does the activation of $\mathrm{Cl}^{-}$conductances through $\mathrm{GABA}_{\mathrm{A}}$ receptors (Sodickson and Bean, 1996). Because $\mathrm{GABA}_{\mathrm{B}}$ receptor-mediated IPSPs are only generated with strong activation of GABAergic synapses (Dutar and Nicoll, 1988a,b), these results support the hypothesis that $\mathrm{GABA}_{\mathrm{B}}$ receptors responsible for the slow IPSP are located extrasynaptically.

The generation of prolonged trains of action potentials in PGN cells resulted in postsynaptic IPSPs that increased and then decreased in amplitude. The reduction in IPSP amplitude may contribute to the "waning" of spindle waves or the antagonism of synchronized oscillations, although this influence is most likely minor, because block of $\mathrm{GABA}_{\mathrm{B}}$ receptors, which generally reduces or blocks reduction of IPSP amplitude during repetitive stimulation (see Thompson et al., 1993; Wu and Saggau, 1995), does not markedly affect the generation of spindle waves (Bal et al., 1995a,b; U. Kim and D. A. McCormick, unpublished observations). In addition, block of the hyperpolarization-activated cation current $I_{h}$ results in the generation of continuous spindle waves, suggesting that reductions in synaptic transmission are insufficient by themselves to halt the generation of these synchronized oscillations (Bal and McCormick, 1996; Luthi et al., 1998).

As with the PGN input onto thalamocortical cells, burst firing in thalamocortical neurons was especially effective in activating hyperpolarized PGN cells, because of temporal summation of the EPSPs during the burst. Interestingly, we did not observe any noticeable changes in the amplitude of these EPSP barrages with repetitive burst firing, indicating that decrement of this synaptic connection is also unlikely to contribute to the waning of spindle waves.

With the PGN in the tonic firing mode, barrages of EPSPs generated by burst firing in thalamocortical cells were only effective in activating an extra action potential in the PGN neuron. Presumably this results from the large currents involved in the generation of action potentials overriding the relatively small currents generated by EPSPs arriving from a single thalamocortical neuron. However, when the PGN cells are hyperpolarized, the EPSP barrages can trigger the low-threshold $\mathrm{Ca}^{2+}$ current and therefore generate a high-frequency burst discharge. The findings that burst firing in PGN cells is essential to the generation of IPSPs that are large enough in amplitude to result in the generation of rebound burst firing in thalamocortical cells and that thalamocortical cells need to be hyperpolarized for this to occur suggest that the generation of synchronized slow oscillations such as spindle waves (and some forms of spike-and-wave seizure) may require that both PGN and thalamocortical cells be in the hyperpolarized state. Indeed, we have shown previously that depolarization of either thalamocortical cells or PGN neurons into the tonic firing mode with the application of various 
neurotransmitters results in an abolition of spindle wave generation (Lee and McCormick, 1996, 1997).

\section{Summary}

Thalamocortical activity exhibits at least three distinct states in vivo: tonic activity during waking and REM sleep, repetitive burst firing during non-REM sleep, and high-frequency, prolonged burst firing during some forms of generalized seizures (Steriade et al., 1986; McCormick and Bal, 1997). Our results demonstrate that these three functional states of the thalamus depend in part on the properties of synaptic transmission between the GABAergic neurons of the perigeniculate (thalamic reticular) neurons and thalamocortical cells. During periods of tonic activity of low-tomoderate frequency, the synaptic responses generated in postsynaptic neurons will generate graded changes in membrane potential in the postsynaptic neurons, presumably determining the patterns of action potentials generated in this state. In contrast, the generation of isolated high-frequency burst discharges results in large postsynaptic responses because of temporal summation as well as facilitation (PGN to thalamocortical), thereby allowing these synaptic influences to activate low-threshold $\mathrm{Ca}^{2+}$ spikes in the postsynaptic neuron. Finally, during the occurrence of at least some forms of generalized seizures, PGN (thalamic reticular) neurons may generate prolonged high-frequency discharges, thereby generating large $\mathrm{GABA}_{\mathrm{B}}$ receptor-mediated IPSPs in postsynaptic thalamocortical cells. These slow IPSPs may then slow the interaction between these two cell types to a frequency in which each thalamocortical cell can discharge with each cycle of the oscillation (Bal et al., 1995b; Kim et al., 1997; SanchezVives and McCormick, 1997), resulting in a "paroxysmal" discharge in which all cells discharge in mass synchrony. These hypotheses remain to be examined in detail.

\section{APPENDIX}

Our present physiological recordings, together with previous anatomical results (Kim et al., 1997), allow us to calculate the approximate degree of convergence and divergence of synaptic connections between cells in the PGN and A-laminae of the LGNd.

\section{Convergence from perigeniculate to thalamocortical neurons}

Our physiological and morphological results indicate that each PGN cell gives rise to a relatively strong connection to at least a subset of thalamocortical cells. In the five examples that we examined, we identified 11, 60, 62, 69, and 69 putative synaptic contacts from a single PGN cell onto a postsynaptic thalamocortical cell (Kim et al., 1997). These numbers are considerably higher than that reported for innervation of pyramidal cells by various types of interneurons in the hippocampus and cerebral cortex, where each interneuron innervates individual pyramidal cells through 5-12 synapses (Somogyi et al., 1983; Buhl et al., 1994). Previously, it has been estimated that thalamocortical cells in the cat LGNd receive from 4000 to 5000 synaptic inputs each (Wilson et al., 1984) and that $\sim 25 \%$ of these are GABAergic (Montero, 1991). GABAergic synapses on thalamocortical cells arise both from intrageniculate GABAergic neurons, which possess both dendrodendritic and axonal synaptic outputs onto thalamocortical cells, and from the perigeniculate nucleus, as well as from other extrageniculate sources (see Uhlrich and Cucchiaro, 1992). At present it is not known what percentage of GABAergic synapses arise from the PGN. We estimate that the average IPSP amplitude of $4.4 \mathrm{mV}$ is generated by $\sim 30$ synapses
(Kim et al., 1997). If all of the 1000-1250 GABAergic synapses were from PGN cells, then one would expect an average of 33-42 PGN cells to innervate each LGNd thalamocortical neuron. However, considering that a large percentage of GABAergic synapses on thalamocortical cells in the LGNd are from local GABAergic interneurons and that many putative synapses identified on the light level are not actual synaptic contacts, it is likely that this number is a substantial overestimate.

Another method to estimate the number of PGN cells projecting to each LGNd thalamocortical cell is via comparing the spindle wave-associated IPSPs with those associated with activation of a single burst of a PGN cell. During generation of spindle waves, the barrages of IPSPs that arrive in thalamocortical cells are an average of $16.5 \mathrm{mV}$. Considering that PGN cells discharge approximately once every two cycles of the spindle wave (see Fig. $8 A$ ) and do not discharge in complete synchrony, we estimate that 10-20 PGN cells innervate each thalamocortical cell. This number also corresponds to the finding that GABA $_{\mathrm{B}}$ IPSPs are 10-20 times larger during the bicuculline-induced paroxysmal oscillations in comparison with the postsynaptic potential activated by a single PGN cell.

\section{Divergence from perigeniculate to thalamocortical neurons}

In four cells we estimated the number of putative synaptic contacts formed by perigeniculate cells in the LGNd by counting the number of beads or swellings formed by the axons of these cells. These counts ranged from $\sim 3000$ to 5000 synaptic contacts, which is similar to that estimated previously in the cat LGNd (Uhlrich et al., 1991). Because PGN neurons in the ferret LGNd seem to innervate almost exclusively thalamocortical cells [with a smaller component onto intrageniculate PGN-like interneurons (Sanchez-Vives et al., 1996)] and we have observed on the average 30 putative synapses with each neuron, this result suggests that single PGN cells innervate on average from 100 to 170 thalamocortical neurons.

\section{Convergence of thalamocortical to PGN cells}

Although we have not yet determined the number of contacts from a thalamocortical cell onto a single PGN cell, these are likely to be relatively low. The axon collaterals formed by single thalamocortical cells in the PGN typically do not bifurcate extensively nor give rise to dense synaptic plexuses (Ferster and LeVay, 1978; Friedlander et al., 1981; Stanford et al., 1983). Examination of PGN neurons with the electron microscope indicates that they may be densely innervated by terminals from thalamocortical cells (Ide, 1982), suggesting a high degree of convergence from thalamocortical to perigeniculate neurons, which is consistent with the fact that there are many more thalamocortical cells than there are PGN neurons. In our intracellular recordings, the average amplitude of EPSP barrages arriving in thalamocortical cells during the generation of spindle waves was five to eight times larger than that generated by burst discharges in single thalamocortical cells. Considering that thalamocortical cells discharge, on average, once every three cycles during spindle waves (Bal et al., 1995a) and that they are not tightly synchronized during these discharges, we estimate that $20-40$ or more thalamocortical neurons innervate each PGN cell.

\section{REFERENCES}

Ahlsen G, Lindström S, Lo FS (1985) Interaction between inhibitory pathways to principal cells in the lateral geniculate nucleus of the cat. Exp Brain Res 58:134-143. 
Avoli M, Gloor P, Kostopoulos G, Naquet R (1990) Generalized epilepsy. Neurobiological approaches. Boston: Birkhauser.

Bal T, McCormick DA (1996) What stops synchronized thalamocortical oscillations? Neuron 17:297-308.

Bal T, von Krosigk M, McCormick DA (1995a) Synaptic and membrane mechanisms underlying synchronized oscillations in the ferret LGNd in vitro. J Physiol (Lond) 483:641-663.

Bal T, von Krosigk M, McCormick DA (1995b) Role of the ferret perigeniculate nucleus in the generation of synchronized oscillations in vitro. J Physiol (Lond) 483:665-685.

Buhl EH, Halasy K, Somogyi P (1994) Diverse sources of hippocampal unitary inhibitory postsynaptic potentials and the number of synaptic release sites. Nature 368:823-828.

Colquhoun D, Jonas P, Sakmann B (1992) Action of brief pulses of glutamate on AMPA/kainate receptors in patches from different neurones of rat hippocampal slices. J Physiol (Lond) 458:261-287.

Contreras D, Steriade M (1995) Cellular basis of EEG slow rhythm: a study of dynamic corticothalamic relationships. J Neurosci 15:604-622.

Davies CH, Collingridge GL (1993) The physiological regulation of synaptic inhibition by $\mathrm{GABA}_{\mathrm{B}}$ autoreceptors in rat hippocampus. J Physiol (Lond) 472:245-265.

Debanne D, Guerineau NC, Gahwiler BH, Thompson SM (1995) Physiology and pharmacology of unitary synaptic connections between pairs of cells in areas CA 3 and CA1 of rat hippocampal slice cultures. J Neurophysiol 73:1282-1294.

Deisz RA, Prince DA (1989) Frequency-dependent depression of inhibition in guinea-pig neocortex in vitro by $\mathrm{GABA}_{\mathrm{B}}$ receptor feed-back on GABA release. J Physiol (Lond) 412:513-541.

Destexhe A, Sejnowski TJ (1995) G-protein activation kinetics and spillover of gamma-aminobutyric acid may account for differences between inhibitory responses in the hippocampus and thalamus. Proc Natl Acad Sci USA 92:9515-9519.

Dobrunz LE, Stevens CF (1997) Heterogeneity of release probability, facilitation, and depletion at central synapses. Neuron 18:995-1008.

Domich L, Oakson G, Steriade M (1986) Thalamic burst patterns in the naturally sleeping cat: a comparison between cortically projecting and reticularis neurones. J Physiol (Lond) 379:429-449.

Dutar P, Nicoll RA (1988a) A physiological role for $\mathrm{GABA}_{\mathrm{B}}$ receptors in the central nervous system. Nature 332:156-158.

Dutar P, Nicoll RA (1988b) Pre- and postsynaptic GABA $_{B}$ receptors in the hippocampus have different pharmacological properties. Neuron 1:585-591.

Evarts EV (1964) Temporal patterns of discharge of pyramidal tract neurons during sleep and waking in the monkey. J Neurophysiol 27:152-171.

Eysel UT, Pape HC, Van Schayck R (1987) Contributions of inhibitory mechanisms to the shift responses of $\mathrm{X}$ and $\mathrm{Y}$ cells in the cat lateral geniculate nucleus. J Physiol (Lond) 388:199-212.

Ferster D, LeVay S (1978) The axonal arborization of lateral geniculate neurons in the striate cortex of the cat. J Comp Neurol 182:923-944.

Fisher SA, Fischer TM, Carew TJ (1997) Multiple overlapping processes underlying short-term synaptic enhancement. Trends Neurosci 20:170-177.

Friedlander MJ, Lin CS, Stanford LR, Sherman SM (1981) Morphology of functionally identified neurones in the lateral geniculate nucleus of the cat. J Neurophysiol 46:80-129.

Frosch MP, Lipton SA, Dichter MA (1992) Desensitization of GABAactivated currents and channels in cultured cortical neurons. J Neurosci 12:3042-3053.

Gray CM, McCormick DA (1996) Chattering cells: superficial pyramidal neurons contributing to the generation of synchronous oscillations in the visual cortex. Science 274:109-113.

Guido W, Weyand T (1995) Burst responses in thalamic relay cells of the awake behaving cat. J Neurophysiol 74:1782-1786.

Gulyás AI, Miles R, Sik A, Tóth K, Tamamaki N, Freund TF (1993) Hippocampal pyramidal cells excite inhibitory neurons through a single release site. Nature 366:683-687.

Horikawa K, Armstrong WE (1988) A versatile means of intracellular labeling: injection of biocytin and its detection with avidin conjugates. J Neurosci Methods 25:1-11.

Hosford DA, Clark S, Cao Z, Wilson WA, Lin F-h, Morisett RA, Huin A (1992) The role of GABA-B receptor activation in absence seizures of lethargic (lh/lh) mice. Science 257:398-401.

Huguenard JR, Alger BE (1986) Whole-cell voltage-clamp study of the fading of GABA-activated currents in acutely dissociated hippocampal neurons. J Neurophysiol 56:1-18.

Ide LS (1982) The fine structure of the perigeniculate nucleus in the cat. J Comp Neurol 210:317-334.

Isaacson JS, Solis JM, Nicoll RA (1993) Local and diffuse actions of GABA in the hippocampus. Neuron 10:165-175.

Johnson SW, Seutin V (1997) Bicuculline methiodide potentiates NMDA-dependent burst firing in rat dopamine neurons by blocking apamin-sensitive $\mathrm{Ca}^{2+}$-activated $\mathrm{K}^{+}$currents. Neurosci Lett 231:13-16.

Kandel E, Spencer WA (1961) Electrophysiology of hippocampal neurons. I. Afterpotentials and repetitive firing. J Neurophysiol 24: 243-259.

Kim U, Bal T, McCormick DA (1995) Spindle waves are propagating synchronized oscillations in the ferret LGNd in vitro. J Neurophysiol 74:1301-1323.

Kim U, Sanchez-Vives MV, McCormick DA (1997) Functional dynamics of GABAergic inhibition in the thalamus. Science 278:130-134.

Lee K, McCormick DA (1996) Abolition of spindle oscillations by serotonin and norepinephrine in the ferret lateral geniculate and perigeniculate nuclei in vitro. Neuron 17:309-321.

Lee K, McCormick DA (1997) Modulation of spindle oscillations by acetylcholine, cholecystokinin, and $1 S, 3 R$-ACPD in the ferret lateral geniculate and perigeniculate nuclei in vitro. Neuroscience 77:335-350.

Lindström S (1982) Synaptic organization of inhibitory pathways to principal cells in the lateral geniculate nucleus of the cat. Brain Res 234:447-453.

Lindström S, Wróbel A (1990) Private inhibitory systems for the X and $\mathrm{Y}$ pathways in the dorsal lateral geniculate nucleus of the cat. J Physiol (Lond) 429:259-280.

Llinás RR (1988) The intrinsic electrophysiological properties of mammalian neurons: insights into central nervous system function. Science 242:1654-1664.

Luthi A, Bal T, McCormick DA (1998) Periodicity of thalamic spindle waves is abolished by ZD7288, a blocker of $I_{h}$. J Neurophysiol 79:3284-3289.

Magleby KL (1987) Short-term changes in synaptic efficacy. In: Synaptic function (Edelman GM, Gall WE, Cowan WM, eds). New York: Wiley.

Markram H, Tsodyks M (1996) Redistribution of synaptic efficacy between neocortical pyramidal cells. Nature 382:807-810.

McCarley RW, Benoit O, Barrionuevo G (1983) Lateral geniculate nucleus unitary discharge in sleep and waking: state- and rate-specific aspects. J Neurophysiol 50:798-818.

McCormick DA, Bal T (1997) Sleep and arousal: thalamocortical mechanisms. Annu Rev Neurosci 20:185-215.

Miles R (1990) Synaptic excitation of inhibitory cells by single CA3 hippocampal pyramidal cells of the guinea-pig in vitro. J Physiol (Lond) 428:61-77.

Miles R, Wong RK (1986) Excitatory synaptic interactions between CA3 neurones in the guinea-pig hippocampus. J Physiol (Lond) 373:397-418.

Mody I, De Koninck Y, Otis TS, Soltesz I (1994) Bridging the cleft at GABA synapses in the brain. Trends Neurosci 17:517-525.

Montero VM (1991) A quantitative study of synaptic contacts on interneurons and relay cells of the cat lateral geniculate nucleus. Exp Brain Res 86:257-270.

Mott DD, Xie C-W, Wilson WA, Swartzwelder S, Lewis DV (1993) $\mathrm{GABA}_{\mathrm{B}}$ autoreceptors mediate activity-dependent disinhibition and enhance signal transmission in the dentate gyrus. J Neurophysiol 69:674-691.

Mukhametov LM, Rizzolatti G, Seitun A (1970a) An analysis of the spontaneous activity of lateral geniculate neurons and of optic tract fibers in freely moving cats. Arch Ital Biol 108:325-347.

Mukhametov LM, Rizzolatti G, Tradardi V (1970b) Spontaneous activity of neurones of nucleus reticularis thalami in freely moving cats. J Physiol (Lond) 210:651-667.

Munoz DP, Wurtz RH (1995) Saccade-related activity in monkey superior colliculus. I. Characteristics of burst and buildup cells. J Neurophysiol 73:2313-2333.

Murthy VN, Sejnowksi TJ, Stevens CF (1997) Heterogeneous release properties of visualized individual hippocampal synapses. Neuron 18:599-612.

Nathan T, Lambert DC (1991) Depression of the fast IPSP underlies 
paired-pulse facilitation in area CA1 of the rat hippocampus. J Neurophysiol 66:1704-1715.

Nuñez A, Amzica F, Steriade M (1993) Electrophysiology of cat association cortical cells in vivo: intrinsic properties and synaptic responses. J Neurophysiol 70:418-429.

Otis TS, Mody I (1992) Different activation of $\mathrm{GABA}_{\mathrm{A}}$ and $\mathrm{GABA}_{\mathrm{B}}$ receptors by spontaneously released transmitter. J Neurophysiol 67:227-235.

Sanchez-Vives MV, McCormick DA (1997) Functional properties of perigeniculate inhibition of dorsal lateral geniculate nucleus thalamocortical neurons in vitro. J Neurosci 17:8880-8893.

Sanchez-Vives MV, Bal T, Kim U, von Krosigk M, McCormick DA (1996) Are the interlaminar zones of the ferret LGNd actually part of the perigeniculate nucleus? J Neurosci 16: 5923-5941.

Sanchez-Vives MV, Bal T, McCormick DA (1997) Inhibitory interactions between perigeniculate GABAergic neurons. J Neurosci 17:8894-8908.

Scharfman HE, Schwartzkroin PA (1989) Selective depression of GABA-mediated IPSPs by somatostatin in area CA1 of rabbit hippocampal slices Brain Res 493:205-211.

Seutin V, Scuvee-Moreau J, Dresse A (1997) Evidence for a nonGABAergic action of quaternary salts of bicuculline on dopaminergic neurones. Neuropharmacology 36:1653-1657.

Sillito AM, Kemp JA (1983) The influence of GABAergic inhibitory processes on the receptive field structure of $\mathrm{X}$ and $\mathrm{Y}$ cells in cat dorsal lateral geniculate nucleus (dLGN). Brain Res 277:63-77.

Snead OC (1995) Basic mechanisms of generalized absence seizures. Ann Neurol 37:146-157.

Sodickson DL, Bean BP (1996) GABA $_{B}$ receptor-activated inwardly rectifying potassium current in dissociated hippocampal CA3 neurons. J Neurosci 16:6374-6385.

Somogyi P, Kisvarday ZF, Martin KAC, Whitteridge D (1983) Synaptic connections of morphologically identified and physiologically characterized large basket cells in the striate cortex of cat. Neuroscience 10:261-294.

Stanford LR, Friedlander MJ, Sherman SM (1983) Morphological and physiological properties of geniculate $\mathrm{W}$-cells of the cat: a comparison with X and Y-cells. J Neurophysiol 50:582-608.

Steriade M, Deschênes M (1984) The thalamus as a neuronal oscillator. Brain Res Rev 8:1-63.

Steriade M, Domich L, Oakson G (1986) Reticularis thalami neurons revisited: activity changes during shifts in states of vigilance. J Neurosci 6:68-81.

Steriade M, Datta S, Pare D, Oakson G, Curro Dossi R (1990) Neuronal activities in brain-stem cholinergic nuclei related to tonic activation processes in thalamocortical systems. J Neurosci 10:2541-2559.

Steriade M, McCormick DA, Sejnowski TJ (1993) Thalamocortical oscillations in the sleeping and aroused brain. Science 262:679-685.
Tang CM, Margulis M, Shi Q-Y, Fielding A (1994) Saturation of postsynaptic glutamate receptors after quantal release of transmitter. Neuron 13:1385-1393.

Thompson SM, Capogna M, Sanziani M (1993) Presynaptic inhibition in the hippocampus. Trends Neurosci 16:222-227.

Thomson AM (1997) Activity-dependent properties of synaptic transmission at two classes of connections made by rat neocortical pyramidal axons in vitro. J Physiol (Lond) 502:131-147.

Thomson AM, Deuchars J (1997) Synaptic interactions in neocortical local circuits: dual intracellular recordings in vitro. Cereb Cortex 7:510-522.

Thomson AM, Deuchars J, West DC (1993a) Single axon excitatory postsynaptic potentials in neocortical interneurons exhibit pronounced paired pulse facilitation. Neuroscience 54:347-360.

Thomson AM, Deuchars J, West DC (1993b) Large, deep layer pyramid-pyramid single axon EPSPs in slices of rat motor cortex display paired pulse and frequency-dependent depression, mediated presynaptically, and self-facilitation, mediated postsynaptically. J Neurophysiol 70:2354-2369.

Tong G, Jahr CE (1994) Multivesicular release from excitatory synapses in cultured hippocampal neurons. Neuron 12:51-59.

Trussell LO, Fischbach GD (1989) Glutamate receptor desensitization and its role in synaptic transmission. Neuron 3:209-218.

Uhlrich D, Huguenard JR (1996) GABA $_{B}$ receptor-mediated responses in GABAergic projection neurones of rat nucleus reticularis thalami in vitro. J Physiol (Lond) 493:845-854.

Uhlrich DJ, Cucchiaro JB (1992) GABAergic circuits in the lateral geniculate nucleus of the cat. Prog Brain Res 90:171-192.

Uhlrich DJ, Cucchiaro JB, Humphrey AL, Sherman SM (1991) Morphology and axonal projection patterns of individual neurons in the cat perigeniculate nucleus. J Neurophysiol 65:1528-1541.

Wang Z, McCormick DA (1993) Control of firing mode of corticocortical and corticopontine layer $\mathrm{V}$ burst-generating neurons by norepinephrine, acetylcholine, and 1S,3R-ACPD. J Neurosci 13:2199-2216.

Weyand TG, Boudreaux M, Guido W (1997) State-dependent changes in the pattern of bursting in LGN neurons of the sleeping and waking cat Soc Neurosci Abstr 23:170.

Wilson JR, Friedlander MJ, Sherman SM (1984) Fine structural morphology of identified X- and Y-cells in the cat's lateral geniculate nucleus. Proc R Soc Lond [Biol] 221:411-436.

Wu L-G, Saggau P (1995) GABA $_{\mathrm{B}}$ receptor-mediated presynaptic inhibition in guinea-pig hippocampus is caused by reduction of presynaptic $\mathrm{Ca}^{2+}$ influx. J Physiol (Lond) 485:649-657.

Zucker RM (1989) Short-term synaptic plasticity. Annu Rev Neurosci 12:13-21.

Zucker RM (1993) Calcium and transmitter release. J Physiol (Paris) 87:25-36. 